Article

\title{
People-Centric Nature-Based Land Restoration through Agroforestry: A Typology
}

\author{
Meine van Noordwijk ${ }^{1,2,3, * \mathbb{C}}$, Vincent Gitz ${ }^{4}$, Peter A. Minang ${ }^{5}$, Sonya Dewi ${ }^{1}$, Beria Leimona ${ }^{1}$, \\ Lalisa Duguma ${ }^{5}$, Nathanaël Pingault ${ }^{4}$ and Alexandre Meybeck ${ }^{4}$ \\ 1 World Agroforestry (ICRAF), Bogor 16155, Indonesia; S.Dewi@cgir.org (S.D.); L.Beria@cgiar.org (B.L.) \\ 2 Plant Production Systems, Wageningen University \& Research, 6700 AK Wageningen, The Netherlands \\ 3 Agroforestry Research Group, Brawijaya University, Malang 65145, Indonesia \\ 4 Centre for International Forestry Research (CIFOR), Bogor 16115, Indonesia; V.Gitz@cgiar.org (V.G.); \\ nathanael.pingault@gmail.com (N.P.); A.Meybeck@cgiar.org (A.M.) \\ 5 World Agroforestry (ICRAF), Nairobi 00100, Kenya; A.Minang@cgiar.org (P.A.M.); \\ L.Duguma@cgiar.org (L.D.) \\ * Correspondence: m.vannoordwijk@cgiar.org
}

Received: 30 June 2020; Accepted: 28 July 2020; Published: 29 July 2020

\begin{abstract}
Restoration depends on purpose and context. At the core it entails innovation to halt ongoing and reverse past degradation. It aims for increased functionality, not necessarily recovering past system states. Location-specific interventions in social-ecological systems reducing proximate pressures, need to synergize with transforming generic drivers of unsustainable land use. After reviewing pantropical international research on forests, trees, and agroforestry, we developed an options-by-context typology. Four intensities of land restoration interact: R.I. Ecological intensification within a land use system, R.II. Recovery/regeneration, within a local social-ecological system, R.III. Reparation/recuperation, requiring a national policy context, R.IV. Remediation, requiring international support and investment. Relevant interventions start from core values of human identity while addressing five potential bottlenecks: Rights, Know-how, Markets (inputs, outputs, credit), Local Ecosystem Services (including water, agrobiodiversity, micro/mesoclimate) and Teleconnections (global climate change, biodiversity). Six stages of forest transition (from closed old-growth forest to open-field agriculture and re-treed (peri)urban landscapes) can contextualize interventions, with six special places: water towers, riparian zone and wetlands, peat landscapes, small islands and mangroves, transport infrastructure, and mining scars. The typology can help to link knowledge with action in people-centric restoration in which external stakeholders coinvest, reflecting shared responsibility for historical degradation and benefits from environmental stewardship.
\end{abstract}

Keywords: assisted natural regeneration (ANR); co-investment; ecosystem services; environmental stewardship; equity; forest and landscape restoration (FLR); landscape approach; rights-based approach; tree planting; water

\section{Introduction}

With the Bonn Challenge (2011) [1], the New York Declaration on Forests (2014) [2] and the UN Decade on ecosystem restoration [3] launched in March 2019, forest and landscape restoration (FLR) is gaining traction on the global political agenda. Within the goal of reversing centuries of damage to forests, wetlands, and other ecosystems, getting it right will be key to putting the planet back on a sustainable course. However, despite the high level of political engagement; despite the number and diversity of actors and institutions involved, from public and private sectors, civil society and local communities, research, and academia, at all levels, from local to global; and beyond some success 
stories, restoration is not happening at scale. As agriculture is a major driver of degradation but remains a primary source of rural livelihoods, international agricultural research can be part of the solution, contributing to the design of successful restoration approaches to be implemented at scale in the coming years.

As part of the international agricultural research consortium (CGIAR) as food security-oriented international agricultural research body [4], the partners in the Forests, Trees and Agroforestry (FTA) program, building on many decades of research, identified the need to uncover the diverse understandings and perspectives about 'restoration' and to construct a typology that can help to clarify contrasts, similarities and possible synergies across the many starting points for targeted interventions that are currently propagated and implemented under the common heading of 'restoration' of forests, landscapes and/or land. The aim of such typology is to better describe links between evolving knowledge, stakeholder-driven action, and achievement of Sustainable Development Goals.

As a first step toward such a typology of restoration as part of international agricultural research, three Common Research Programs (CRPs) of the CGIAR-Forests, Trees and Agroforestry (FTA), Policies, Institutions and Markets (PIM) and Water, Land and Ecosystems (WLE)—conducted a joint stocktaking of CGIAR work on forest and landscape restoration [5]. They covered a wide range of field projects and case studies, decision making supporting tools, modeling, mapping, conceptual approaches, and frameworks across the geographical area of interest of the CGIAR, i.e., the tropics and sub-tropics in Africa, Asia, and Latin America. They covered a broad range of issues directly or indirectly related to restoration, including sustainable land and water management; seed supply systems and genetic diversity; climate change adaptation and mitigation: land tenure security and land governance reform. They showed how restoration efforts could contribute to SDG2 by supporting smallholder farmers' ability to increase food production, while also addressing SDG15 "protect, restore and promote sustainable use of terrestrial ecosystems" and "halt and reverse land degradation", contingent on SDG16 "peace, justice and strong institutions", assist with SDG6 "availability and sustainable management of water and sanitation for al", and most, if not all the 17 sustainable development goals [6]. They unveiled the many drivers of land degradation, not only biophysical, but also socio-economic, political, and institutional and the variety of actors involved. They suggest different ways to categorize restoration interventions.

Building on the results of this survey, the main objective of this paper is to elaborate a typology of restoration options by context applicable in a wide range of situations across the tropics and sub-tropics. We adopt here a people-centric nature-based perspective focusing on land restoration through agroforestry. For that purpose, Section 2 discusses the underlying concepts and definitions and presents our approach. Section 3 focuses on land degradation, its symptoms, drivers, and indicators. Section 4 suggests and discusses a possible typology of restoration options by context.

\section{Underlying Concepts, Definitions and Approach}

\subsection{Beyond Tree Planting, the Various Aspects of Restoration}

Tree planting as a way to restore local ecosystems appeals to many farmers, local communities, national policymakers, and private companies, for a variety of reasons. Tree planting ceremonies as a symbol of peace and commitment to stability and prosperity have an important place in the diplomatic world and national policy agendas for post-disaster contexts [7]. The 'tree planter hero' portrayal has strong emotional appeal [8-10]. Claims of the millions, billions [11,12] or trillions [13] of trees planted capture the public imagination and get news headlines. More than seven billion humans share the planet with approximately three trillion trees [14] 46\% less trees than at the start of human history. Approximately 1.36 trillion of these trees exist in tropical and subtropical regions 0.84 trillion in temperate regions and 0.84 trillion in the boreal region; overall nearly one-third are outside forests [15]. Tree diversity in agroforestry landscapes varies over three orders of magnitude, from 1-1000 [16]. 
Enthusiasm for tree planting only partially aligns with the focus of thousands of experts around the world who have dedicated their professional lives to the protection and restoration of ecosystems [17]. Guidelines for restoration include recommendations to first consider and deal with root causes of degradation, to work with nature, rather than against it with technical means, and to work with people. The guidelines suggest that experts can provide advice on where and how tree planting can be helpful. The idea, however, that planting trees is at the core of restoration ignores the expertise of millions of agroforesters (practitioners) around the world who learned that people-centric and nature-based land restoration through agroforestry can be as simple as 'assisted natural regeneration', with selective retention of the right trees growing in the right places [18,19]. While the practice may be as old as agriculture, agroforestry as a branch of applied science started four decades ago. 'Restoration' was and still is one of its main motivators [20-23]. Where it is ecologically and socially feasible [24-27], approaches such as assisted natural regeneration need to be upfront part of a 'restoration typology' message and list of options to be considered for any given context. In a more comprehensive 'options by context' typology for restoration a wider spectrum of activities beyond 'tree planting' is needed, as we will explore in this contribution.

The growing consensus on the relevance of a social-ecological systems perspective has seen restoration ecology [28-30] and forestry-oriented implementation guidelines [31-33] evolving to restoration science [34-37]. This meant a stronger social orientation [38-40], with attention to success factors for community forestry [41,42]. Yet agendas on food security [43] and public health [44] remain poorly connected to the dominant restoration discourse. A gap still exists between Land Restoration from an agricultural perspective, as perceived in CGIAR efforts [9], and the main ideas in Forest and Landscape Restoration. The wording of principles of Forest and Landscape Restoration [45], such as "Engage stakeholders and support participatory governance", "Taylor to the local context using a variety of approaches", "Manage adaptively for long-term resilience" suggest a genuine attempt to connect with bottom-up farmer perspectives, but also serious challenges to actually achieve that. Principles such as "Restore multiple functions for multiple benefits" may be redundant if local stakeholders have a real say in what happens on the ground. A list of common governance challenges for Forest and Landscape Restoration in a recent review [46] included (1) Poor alignment across levels and sectors of government, (2) Environmental and social heterogeneity, (3) Lack of enabling conditions and implementation capacity. A non-involved reader might wonder whose agenda such type of restoration actually is. Thus, a recent review of FLR practice concluded that "Existing guidelines and best practices documents do not satisfy, at present, the need for guiding the implementation of Forest and Landscape Restoration (FLR) based on core principles. Given the wide range of FLR practices and the varied spectrum of actors involved, a single working framework is unlikely to be effective, but tailored working frameworks can be co-created based on a common conceptual framework" [47]. While FLR is supposed to support sustainable agricultural production, there is very little discussion on how this can be achieved. When farmers are asked about their own decision making with regards to landscape restoration, responses may be surprising. Recent efforts to obtain a deeper understanding of farmer decision making for landscape restoration in Malawi revealed that the expectations that 'planting more trees will attract reliable rains' figured prominently in local perspectives, before expected benefits for soil fertility or beekeeping [48]. One of the milestones of restoration science is the "reference ecosystem", specifying the desired successional stage of recovery, the species (or group of species) that are the target of rehabilitation and the expected time of recovery of the degraded ecosystems after initial treatment (change in management). Follow-up questions are whether the time involved is socially accepted, economically feasible and ecologically reasonable.

One of the key propositions of the paper is to advance restoration science to a more complex set of objectives and functions to be restored and to put local land users at the center of the process. The confrontation, managing synergies, and trade-offs between such functions, and at nested scales, is fundamental to the challenge, and in line with decades of analysis of landscape multifunctionality and integrated natural resource management in international agricultural research $[49,50]$. Rather than 
a static reference ecosystem continued change and agility will be needed as a vision for multi-functional restoration [51]. Therefore, we propose to extend the concept of "reference ecosystem" to the "reference social-ecological system" and resulting functions.

Innovation, development, intensification, adaptation, rejuvenation, and restoration appear to refer to different actions, with emphasis on the new, the existing or the past. In practice, however, similarities exceed the differences as all need to deal with motivation, rights, know-how, markets, environment from local environmental effects to global effects through bio-geochemical and hydrological cycles and their global teleconnections [52-54]. This means that all efforts need to match options for interventions to context at the nested scales of farms, landscapes, nation-states, and the changing global context. This means involving a multiplicity of actors: farmers, communities, private sector, public sector, and global investors [55-59]. Interventions also range from projects and programs to wider policies at national or even international (regional) level [60]. Unless these are people-centric, however, their chance of sustainable success is small [61,62]. Land restoration, as we present it and contrarily to what the word often means in other contexts, is not backward-looking but forward-looking. Innovative restoration (or restorative innovation) reconciles historical path-dependency of the degraded status quo with forward-looking theories of induced change that are empirically grounded, rather than wish-lists of over-optimistic planners. It requires science-based and across-scales diagnosis of the underlying causes ('driving forces') that shaped current context, mobilizing a wide range of conceptual frameworks to understand social-institutional constraints, drivers of change and sustainers of long-term action. It then relates that context to options for interventions. Common interventions in land restoration focus on modifying land cover or structural land surface properties but are aimed at improvement of land use and functionality in support of multiple goals.

Land cover change can be achieved through natural regeneration (with various degrees of human assistance and farmer management), tree and grass planting (with its dependence on seed supply and nursery value chains), or remediating management of soil and water. Land-use change depends on who is allowed to be a user, for what purpose and for what use, their motivation, preferences, restrictions, the know-how of managing land in local contexts, market opportunities, concerns about local environmental impacts and external co-investment in land stewardship. Across all modes of regeneration there are tree genetic resources issues [63-65], agronomic options in context [66,67],value chains [68-70], hydrology [71], global teleconnections through climate [72,73], and biodiversity [74-76], as well as policy reform of rights [77], cross-scale incentive systems for stewardship [78-80], and distributional and process concerns over equity and inclusiveness [81]. Key constituencies (including policy-makers, funders, local stakeholders, scientists) need commonly understood metrics to achieve progress [82,83]. Restoration is commonly differentiated by geographic contexts, such as China [84], Southeast Asian fallow to forest transitions [85], East and South African drylands [86], Horn of Africa [87], or Brazil [88]. Still, a more incisive way of describing similarities and differences is needed.

\subsection{Definitions}

The Society for Ecological Restoration (SER) [89], in line with the Intergovernmental Science-Policy Platform on Biodiversity and Ecosystem Services (IPBES) [90] defines ecological restoration as "any activity with the goal of achieving substantial ecosystem recovery relative to an appropriate reference model, regardless of the time required to achieve recovery. Reference models used for ecological restoration projects are informed by native ecosystems, including many traditional cultural ecosystems". Both the SER and the IPBES distinguish ecological restoration from rehabilitation. The latter refers to restoration activities that aim at "reinstating a level of ecosystem functioning for renewed and ongoing provision of ecosystem services potentially derived from nonnative ecosystems as well" [79] but may "fall short of fully restoring the biotic community to its pre-degradation state" [80]. Both see restoration activities as a continuum, from rehabilitation to ecological restoration, aiming at initiating or accelerating the recovery of an ecosystem from a degraded state. These various acceptances of the 
term 'restoration' reflect the various perspectives, motivations and behaviors of the different actors involved. While ecologists, scientists, and activists might focus more on ecological restoration as the return to a pristine state of natural ecosystems, governments and economists may be more interested in a discourse focusing on regaining ecological functionality in degraded landscapes in order to enhance food security and livelihoods, reduce poverty and contribute to sustainable development. In line with this latter perspective, in the context of the Bonn Challenge, the International Union for Conservation of Nature (IUCN) and other partners adopted the following definition [91]: "Forest landscape restoration (FLR) is the ongoing process of regaining ecological functionality and enhancing human well-being across deforested or degraded forest landscapes. FLR is more than just planting trees-it is restoring a whole landscape to meet present and future needs and to offer multiple benefits and land uses over time".

For the purpose of this paper, the term 'restoration' encompasses the whole continuum of restoration activities, from rehabilitation to ecological restoration, covers any kind of ecosystems (natural forest, agroforest or agricultural landscapes) and gives a central place to the concept of 'ecological functions' (Figure 1), i.e., the functions that allow ecosystems to generate various regulating, supporting, provisioning and cultural benefits to people or 'services' [92], including those generating direct economic value.

Building on these considerations, this paper adopts the following definitions:

- Degradation: Loss of functionality of e.g., land or forests, usually from a specific human perspective, linked to a change in land cover with consequences for (at least one category of) ecosystem services,

- Degraded lands: Lands that have lost functionality beyond what can be recovered by natural processes and existing land use practices in a defined, policy-relevant time frame,

- Syndrome: Set of concurrent diagnostical indicators or symptoms that can be the result of different and often interacting causes or drivers,

- Restoration: Efforts to halt ongoing and reverse past degradation, by aiming for increased functionality of ecosystems supporting land use (not necessarily recovering past system states)

Restoration covers a broad range of changes (innovations) relative to the current system state-from land use practices and land cover changes to physical infrastructure and institutional changes. As highlighted above, the objective here is to regain ecological functionality and enhance human well-being, not necessarily to go back to the initial ecosystem state or function. That may simply be impossible in some places because of the change in local demographic conditions. Living with the current 7 billion people on the planet would not allow that. Moreover, the final 'restored' state of the ecosystem shall be self-sustaining. This means that in a particular context, given the set of ecological functions to 'restore', restoration interventions need to lead to social, economic, and ecological benefits lasting in the long-term. While in other aspects of human life binary classifications have been recognized as being problematic, past distinctions between 'Nature' (ecosystems, wilderness) and human endeavors (agro-ecosystems, plantations, (peri)urban systems) remain evident in the way 'ecological restoration' is distinguished from 'forest and landscape restoration'. Under the heading 'land restoration' we aim to bridge this divide. Therefore, we propose here a broader umbrella to clarify the full perspective of 'stopping degradation plus recovering damage' and addressing in a sustainable way the underlying drivers, including those related to the production function of the lands and to the needs of people living in it and from it. Reconciling these perspectives is critical to the sustained, long-term success of land restoration and especially relevant in the pan-tropical domain. Dealing with the generic drivers of degradation, rather than area-specific pressures, builds on decades of policy development, although progress on Aichi 2020 target of the Convention of Biological Diversity on pollution control is less than that on target 11 achieving an increase in protected areas. [93]. 


\subsection{The Social-Ecological Cascade Framework}

The distinctions between land cover (as structure) and land use (as a set of services derived) are compatible with a Social-Ecological System (SES) cascade (Figure 1A) [94]. Mainstream 'forest' definitions combine aspects of scale (minimum area), structure (tree cover, tree size), function (primary designated purpose) and institutional control by forestry agencies, segregating trees into 'forestry' and 'agricultural' ones [95,96]. Important parts of the structure are also the condition of the topsoil (including its soil organic matter [97], protective litter layer, macroporosity [98] and soil biota), while the related functions include processes such as rainfall infiltration and (absence of) surface runoff and erosion [99].

Feedback options from 'stakeholders' based on the values at stake for them to 'actors' in the landscape make the cascade flow into a social-ecological system with self-adjustment or learning ability. These feedbacks link 'bio-geo-physical' units, social actors and institutions, across scales. Many changes in the landscape increase some and decrease other functions and values, and as such they are either degradation or restoration depending on the weight given to various functions by stakeholders, or the strength of their voice in public discourse. Post-logging forest management to increase the growth of the most desirable species, may imply degradation from an ecological perspective, for example. Draining swamps for improved public health, implies ecological degradation, as a second example. The feedback loops that aim to shift ongoing degradation toward restoration require specific ways of linking knowledge (on options in context) with action (getting societal traction on issues and agreement on goals) (Figure 1B). Five issue cycle steps depend on and strengthen the knowledge-action linkages: A. Agenda setting, B. Better and shared understanding of what is at stake, C. Commitment to common principles, often based on coalitions, D. Devolved details of design and delivery, dealing with trade-offs, and E. Efforts to evaluate, and where necessary restart $[50,100]$.

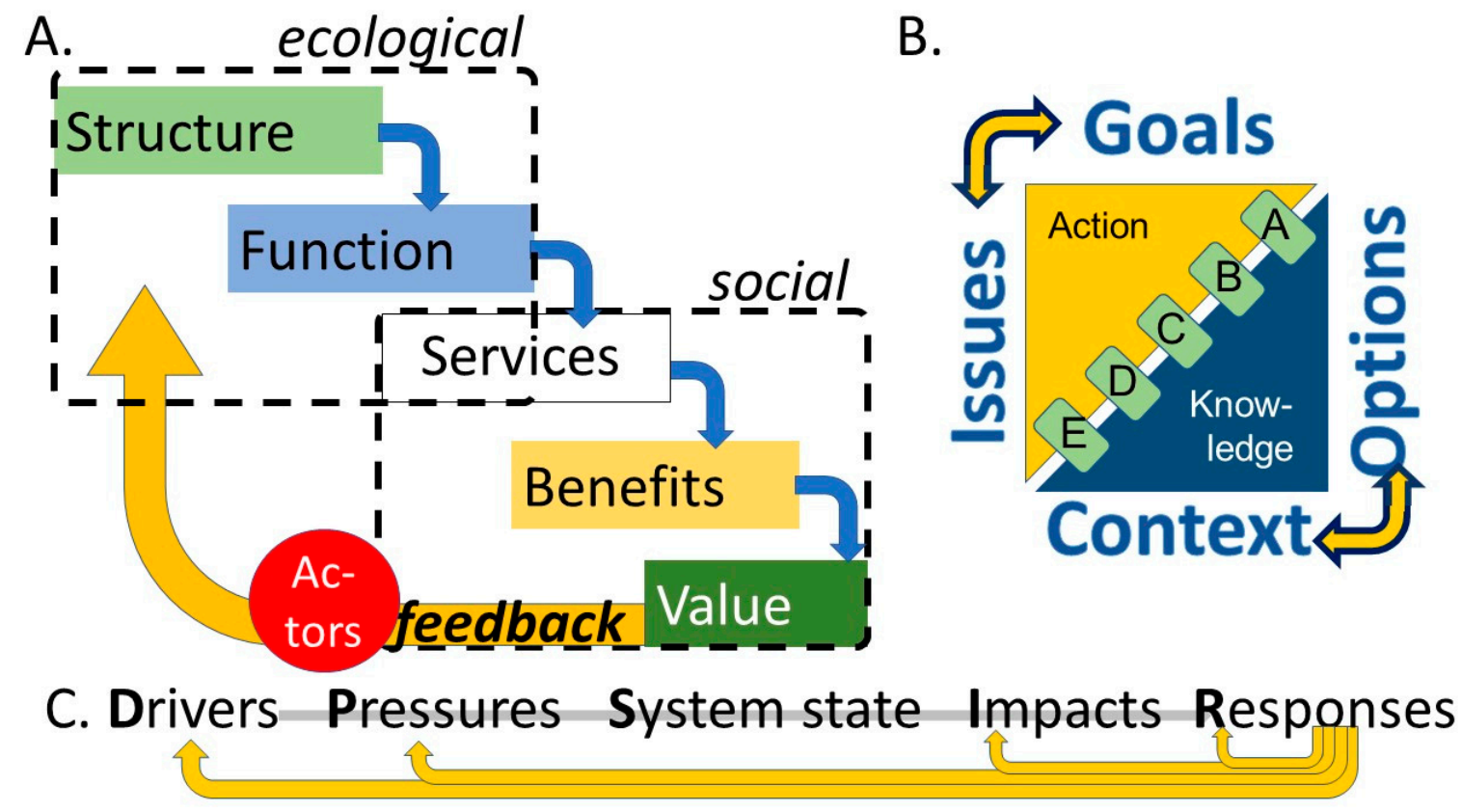

Figure 1. (A) Social-ecological system (SES) as a cascade with feedbacks via actors (modified from [101]), (B) Multiple links between knowledge and action along the intervention cycle, with two-way interactions between issues and goals, as well as between options and context (modified from [50]), (C). Responses can target drivers, pressures, impacts or the emergence of responses itself.

The SES cascade framework and the above-mentioned knowledge-action linkages are conceptually close to a third commonly used framework, which depicts how Drivers, Pressures, State change, Impact and Responses (DPSIR) interact in a feedback loop, with responses addressing the immediate pressures 
and/or the underlying causes (drivers) (Figure 1C). Often Drivers, Pressures and Impacts operate in nested scales, necessitating Responses (including 'restoration') to do the same to be effective.

\subsection{Our Approach}

Interventions to support the restoration of the functionality of lands, forests and landscapes can be many folds, and operate at different scales (local, national, global), involve various combinations of private and public initiatives and investment, relate to the rights and authority of local actors and stakeholders in multiple ways (ranging from eviction to full consultation and respect of Free and Prior Informed Consent (FPIC) or public and private support for local initiatives). These interventions seek various entry points into Social-Ecological Systems other than directly addressing land cover (e.g., by tree planting), such as modified rights, enhanced know-how, supported markets, or incentive systems. These are always related to specific contexts that are in turn very diverse depending on the social-ecological system in place and its historical path-dependency.

The dual purpose of our proposed typology is:

1. to allow a more effective exchange of knowledge and experience between settings where restoration (of any kind) is initiated, planned or in process, based on recognized similarities and contextualized differences, enabling a better confrontation and/or integration of the corresponding evidence-base, and

2. to assist planning and priority setting, especially where scarce public resources are involved.

The first purpose is to reflect an actor-centric (bottom-up) perspective, the second a planner (top-down) one.

As typologies of goals and issues can be derived from other frameworks, such as the set of Sustainable Development Goals (SDG) targets and indicators (or any other national or local level framework), we focus here on the knowledge side of the interaction and thus on a combined typology of intervention options and contexts, within the main steps of issue cycles, as illustrated in Figure 1B [102].

Restoration interventions are chosen out of a wide array of options, supposedly finetuned to the local context. Therefore, to elaborate a typology of restoration options by context, we cross two different typologies:

- a typology of contexts/situations, focused on types and levels of ecological degradation in their social contexts, at the system state level of DPSIR, but with attention to the pressures, drivers and impacts as levels of analysis;

- a typology of options for restoration interventions that address symptoms of ecological degradation and/or its drivers, and/or support the social conditions that sustain further improvement.

The resulting 'restoration' typology positions (combinations of) interventions in a specific context, expecting considerable 'endogeneity' in what is attempted and has success where. Endogeneity is one of the main obstacles to interpreting observable patterns of associations (e.g., forest cover and human well-being) in terms of replicable mechanisms and generic theories of change. Real learning from track records of any intervention elsewhere requires contextualization of its initiation and operationalization.

A technical perspective on restoration takes 'ecosystem structure' as the direct target for interventions, triggering the cascade (Figure 1A) to function, services and human benefits, but a social-ecological perspective starts from the Response part of the DPSIR cycle (Figure 1C) and identifies leverage points (preferably at Driver level), leading to land use change that leads to changes in ecosystem structure (Figure 2). 


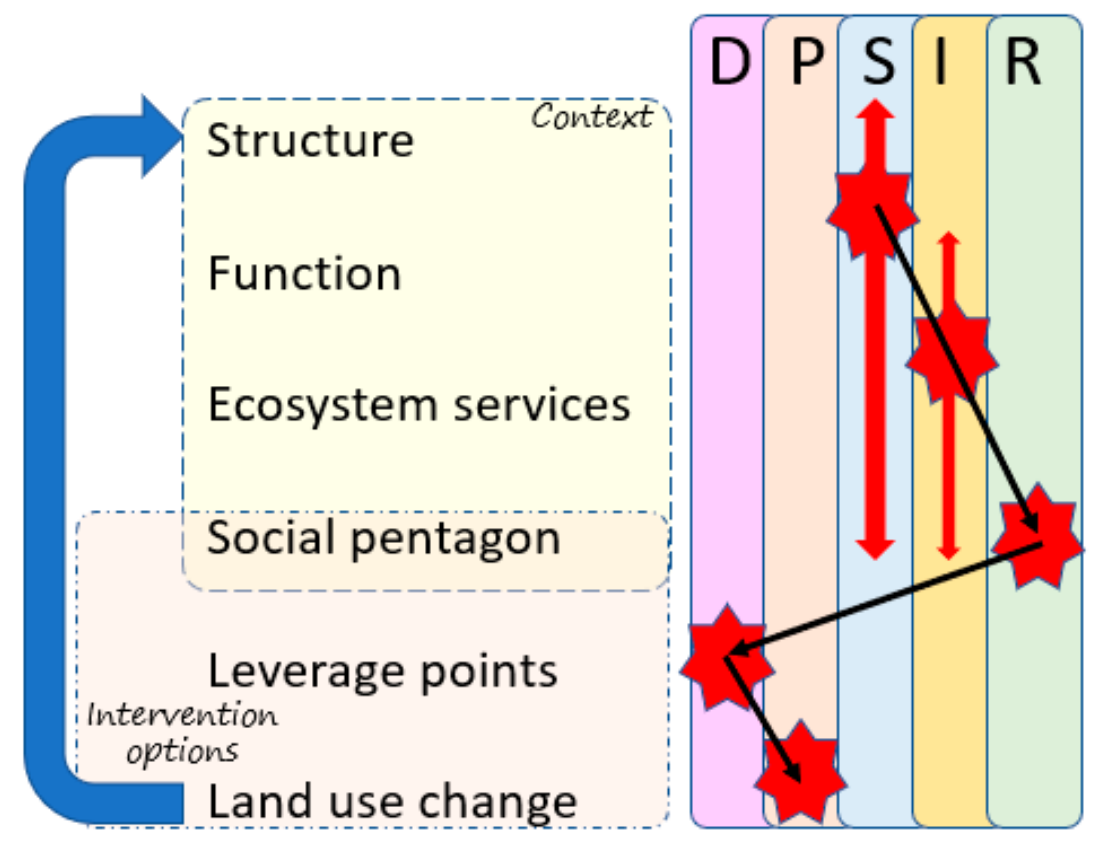

Figure 2. Relating the cascade and DPSIR concepts of Figures $1 \mathrm{~A}$ and $1 \mathrm{C}$, respectively, in social-ecological systems that shift from degradation to restoration; the social pentagon is shorthand for rights, know-how, markets, local ES issues and teleconnections.

\section{Land Degradation: Symptoms, Drivers, and Indicators}

\subsection{Symptoms, Syndromes and Diagnostics}

In a social-ecological system interpretation, the importance of breaking current trends of degradation (loss of functionality) emerges in many different contexts, with a wide range of 'entry points' that get issues inscribed into an agenda for action. These starting points can be compared with 'symptoms' in the medical tradition, signs that something is amiss with system health, but requiring diagnosis. As in the medical tradition a determined set of symptoms can appear concurrently, a syndrome, giving further indications for diagnosis. Diagnosis aims to identify the location-specific pressures (Table 1) and their underlying generic drivers as targets for interventions beyond the symptom level. 
Table 1. Examples of diagnostic links between symptoms along the SES cascade and the underlying pressures (that themselves respond to generic 'drivers' outside the targeted landscape).

\begin{tabular}{|c|c|c|}
\hline Starting Point & Symptom & Example of Contributing Pressures \\
\hline \multirow[t]{6}{*}{ Structure } & Loss of land cover & Uncontrolled conversion \\
\hline & Loss of perennials & Overgrazing \\
\hline & Loss of tree cover & Overlogging, overharvest \\
\hline & Loss of plant diversity & Specialization, markets \\
\hline & Skewed tree age distribution & Lack of rejuvenation investment \\
\hline & Loss of soil structure, carbon & Over-cropping \\
\hline \multirow[t]{5}{*}{ Function } & Reduced primary production & Local climate change, soil fertility loss \\
\hline & $\begin{array}{l}\text { Disturbed hydrology: quantity, quality, } \\
\text { timing of river flow; } \\
\text { freshwater retention }\end{array}$ & $\begin{array}{l}\text { Local climate change, loss of filter and } \\
\text { buffer functions by vegetation }\end{array}$ \\
\hline & $\begin{array}{l}\text { Loss of soil retention, downstream } \\
\text { sedimentation, landslides }\end{array}$ & $\begin{array}{l}\text { Loss of effective land cover, increased } \\
\text { rainfall intensity }\end{array}$ \\
\hline & Spread of uncontrolled fire & Loss of functional fire-breaks \\
\hline & Increase of pest, disease, weed pressures & Disturbed ecology and food-webs \\
\hline \multirow[t]{5}{*}{ Services } & $\begin{array}{l}\text { Loss of harvestable and marketable } \\
\text { production ('provisioning services') }\end{array}$ & $\begin{array}{l}\text { Loss of productivity, consumer trust in } \\
\text { responsible production }\end{array}$ \\
\hline & Decline in usable water, increased floods & Disturbed hydrology \\
\hline & $\begin{array}{l}\text { Loss of net greenhouse } \\
\text { gas sequestration }\end{array}$ & Loss of soil functions, vegetation \\
\hline & Loss of human health & Loss of healthy ecosystems \\
\hline & Loss of cultural and spiritual value & Loss of respect and recognition \\
\hline \multirow[t]{3}{*}{ Benefits } & Loss of local livelihoods & Loss of harvestable/marketable production \\
\hline & Loss of secure and trusted value chains & Production costs, market prices, loss of trust \\
\hline & $\begin{array}{l}\text { Loss of existence value of } \\
\text { global biodiversity }\end{array}$ & Awareness of existence and threats \\
\hline \multirow[t]{4}{*}{ Value } & Increased resource use conflicts & Lack of rights, lack of law implementation \\
\hline & Increased inequity and gender inequity & Lack of voice in decisions \\
\hline & Loss of options for young people & Land shortage, lack of livelihood options \\
\hline & Loss of local ecological knowledge, rules & Lack of attention, respect and rejuvenation \\
\hline
\end{tabular}

Behind the location-specific pressures that lead to degradation in Table 1, there are generic underlying causes (such as population growth, economic growth ambitions, globalization, urbanization and changes in diets and lifestyles) that require generic responses [103]. Such ultimate causes of land degradation cannot be ignored by restoration scientists and practitioners. However, a long history of claims that intensifying agriculture, especially in the tropical forest margins, would by itself reduce environmental impact (known as the 'Borlaug' hypothesis) [104,105] was rejected based on evidence from the field. Agricultural land abandonment, providing space for restoration, may be expected in lessfavorable conditions where agricultural labor moves to cities [106], rather than as a direct consequence of intensified agriculture elsewhere. Population policies, both the migration and birth rate side of them are closely linked to national identity issues, and hardly modifiable by directly environmental concerns or agricultural research [4]. SDG 12 "responsible production and consumption" may be the closest approximation among the SDGs to deal with market-related drivers of degradation and restoration, but the goal is largely aspirational, with weak operationalization [107].

\subsection{Structural Indicators: Tree Cover Linked to Ecological Functions}

Restoration issues can start with any of the five elements of the SES cascade of Figure 1: structure, function, services, benefits, or value, and need to identify where 'lack of' function is caused by 'loss of' function. At the highest level of this cascade is the category Land or Land Health, as vegetation and surface soil are parts of the structure-which also is most readily observed. Remote sensing has so far had a dominating role in informing top-down priority setting for restoration interventions, but it does not always allow separating anthropogenic change from natural patterns of variation. Anthropogenic 
changes (over time) in land cover and surface soil structure such as tree cover transitions (also known as forest transition (FT)) interact with two other dimensions of tree cover variation: latitude and topography, jointly shaping climate and soils. The natural spatial distribution of vegetation types responds to climate and soil, with temperature and rainfall varying by both latitude (from tropics to boreal) and topography and water availability in any given climate by topographical variation in water acquisition and drainage (Figure 3).

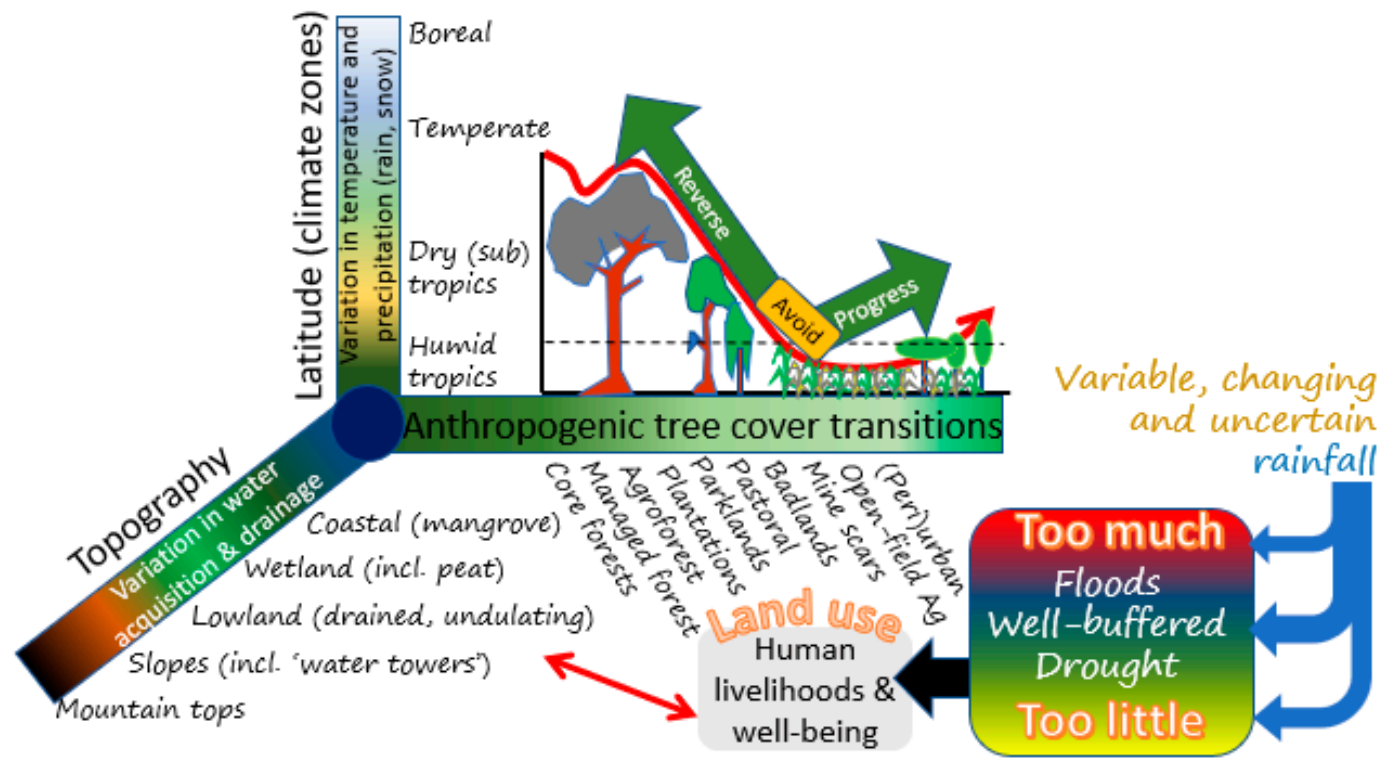

Figure 3. Three major sources of spatial variation in tree cover: latitude, topography and place-based anthropogenic tree cover transition in interaction with rainfall regimes as the cause of water excess, shortage or well-buffered conditions (modified from [54]).

Tree cover in itself cannot be a universal proxy for land degradation or restoration, or for assessing the human influence in the SES cascade. For example, vegetation with $20 \%$ tree cover could be the natural vegetation in semi-arid conditions or on mountain slopes but indicates human influence elsewhere (e.g., increased fire frequency in anthropogenic savanna conditions). With several of the worst effects of 'degradation' related to disturbed hydrology (e.g., floods and droughts), one needs to unpack anthropogenic effects from natural background variation.

The forest transitions (FT) typology [108], illustrated in Figure 3 and presented in more detail in Section 4.4, clarified that the highest human population densities (FT6) in a pantropical study were associated with around 30\% tree cover at sub-watershed scale (Figure $4 \mathrm{~A}$ ), while areas with less tree cover (e.g., open-field agriculture) are associated with lower population densities (Figure 4B). Within the humid and (per)humid tropics there is a strong negative relationship of the 'more people, less forest' type (Figure 4D), but in arid and semiarid an opposite trend (more people, more trees) can be noted (Figure 4C). 

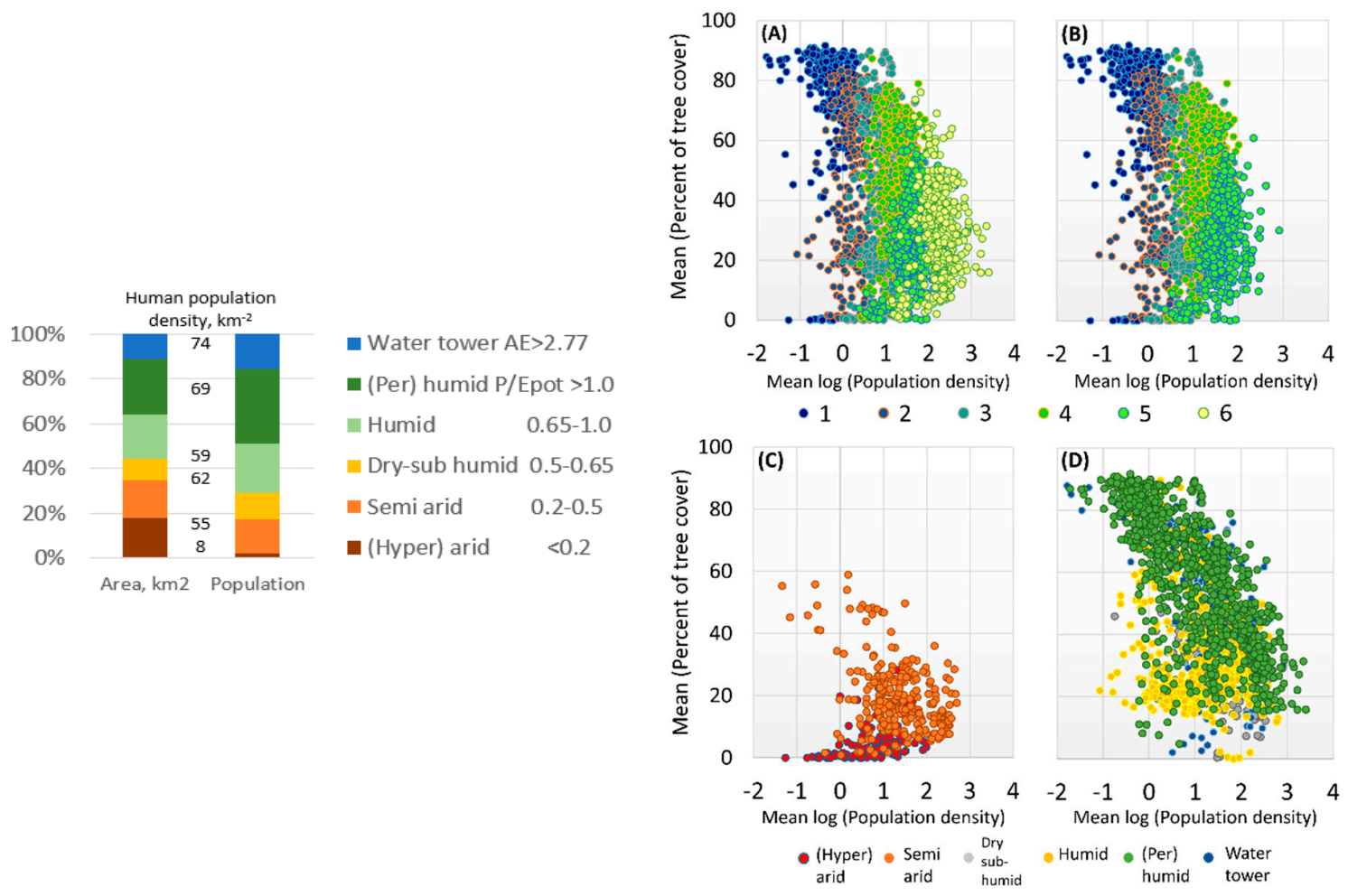

Figure 4. (Left panel): area and human population size in the tropics in five climatic zones (defined on the basis of the ratio of precipitation $\mathrm{P}$ and potential evapotranspiration $\mathrm{E}_{\text {pot }}$ and the water tower configuration as defined in [108]); (Right panel): pantropical relationships at sub-watershed level between human population density and tree cover, for six identified stages of forest transition FT and the six climate zones as defined in [108]; (A) for all sub-watersheds differentiated by forest-transition stages; (B) only for sub-watersheds of stages 1-5; (C) for sub-watersheds within (hyper-) arid and semi-arid zones; (D) for sub-watersheds in the remaining agro-ecological zones.

Reductions, rather than the expected increases, in streamflow are a common result of tree planting and forest restoration [109] that do not have to come as a surprise. Depending on the environmental conditions an intermediate tree density can be optimal from a groundwater recharge perspective [110], while desirable effects on flood-causing peak flows can be stronger than undesirable reductions in annual water yield [111,112]. Flood control may depend on using trees as part of river restoration [113] rather than blanket reforestation of landscapes. Increasing attention to the rainfall-generating effects of high evapotranspiration $[114,115]$ justifies renewed attention to the savanna-forest hysteresis theory of local climate influences [116,117].

\subsection{Social Indicators: Services, Benefits And Values}

At the lower part of Table 1 we see closely connected, primarily socially defined, indicators of services, benefits, and value. While there are many ways to unpack the complexity further (e.g., the 'five capital' framing), we found five aspects that operate at the landscape scale and capture important dimensions of human well-being. These five aspects illustrated by the 'social pentagon' (Figure 5), are discussed in more detail in the next section. 


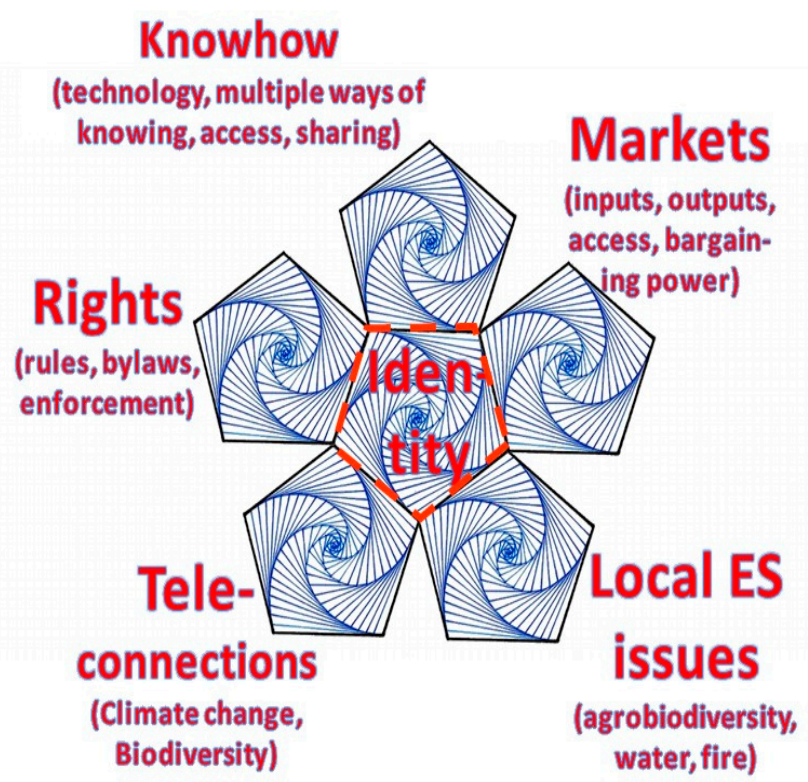

Figure 5. Representation of six key attractors of attention in Social-Ecological Systems that relate to both degradation and restoration phases.

\section{Typology of Interventions}

\subsection{The Social Pentagon as a Starting Point for a Typology of Restoration Options}

At the heart of the social pentagon (Figure 5) a lost or modified sense of identity may be the worst impact of degradation and has to be on the basis of any success in restoration. Human identity (self-image) relates to local institutions (that include education, religion, cultural values, collective action), motivation, usually stratified by age- and gender, as well as to other dimensions such as social stratifiers of wealth and influence (e.g., caste, social class, patronage, entrepreneurship, or other aspects of political ecology).

Identity and the human capacity to adapt to gradual degradation processes can be the main obstacle to transformative change or to tackling the underlying degradation drivers, often requiring an external event such as a disaster to trigger or catalyze the needed transformative changes. As noted in a review for Southeast Asia, many examples of locally led restoration have a dearly paid locally learned lesson of a disaster (including landslides, floods, drought, fire) as their turning point in local history, generating the energy needed to overcome vested interests and status quo degradation [118].

Identity interacts with rights (as defined at national scale in laws governing forests, tenure and inheritance rules, and land-use planning, or in local bylaws clarifying stewardship and collective action), know-how (accumulated in local knowledge and interacting with externally supported ways of knowing), markets (for both inputs such as planting materials and products), local ecosystem service issues (often with water, microclimate, agrobiodiversity and fire as focal points of concern) and global teleconnections, interactions and feedback loops (especially those regarding climate change and biodiversity conservation).

A substantial body of case studies and action research engagements in Africa and Asia tested several ecological, economic, social, and governance propositions on the way 'Payments for Ecosystem Services (PES)' may have to be renamed 'Co-investment in Environmental Stewardship' to understand sensitivities and misunderstandings that arise from the most commonly used terminology [119]. The risk of 'crowding' social motivation for pro-environmental behavior by a focus on financial transactions was demonstrated to exist experimentally [120] but depends on the communication of programs and opportunities for local re-interpretation of terms [121].

The social pentagon interacting with identity defines not only the ultimate effect of degradation, it also forms the starting point of interventions for change (Figure 6), challenging the neat two-way 
options by context typology by emphasizing that it needs to be considered along an issues-cycle of awareness, motivation for change and steps toward a break with the past.

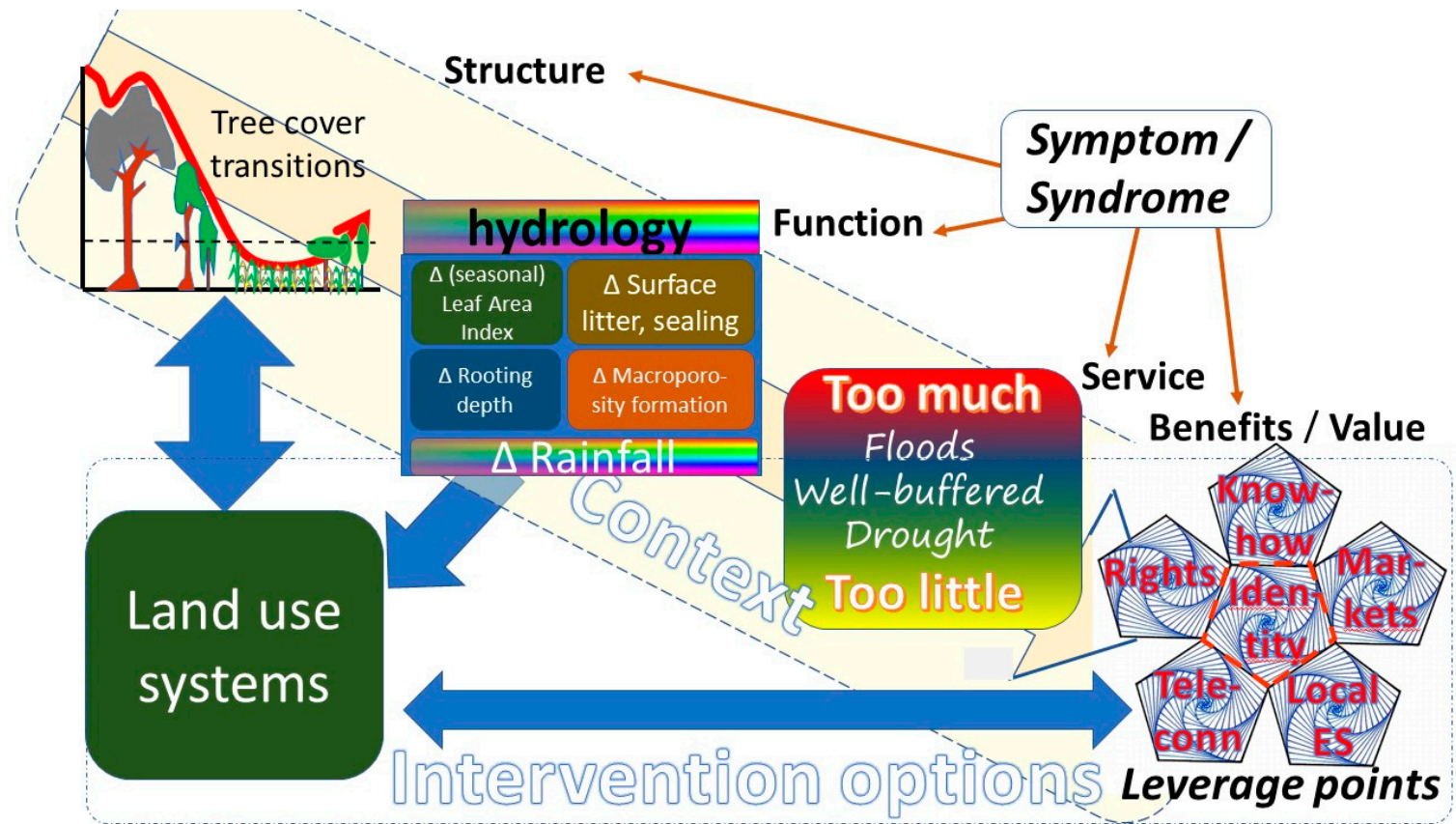

Figure 6. Connecting typologies of degradation/restoration context with intervention options through leverage points in the social pentagon and core identities.

While specific 'development' organizations take rights-, knowledge-, or market-based approaches as their starting point for restoration interventions in local social-ecological systems, trying to nudge current degradation into a restoration and innovation trajectory, 'conservation' organizations have focused on globally important teleconnections (climate, biodiversity, footprints of commodity trade) and/or local ecosystem services and associated local livelihoods. Regardless of the starting point, however, the relevance of an integrative livelihood orientation that relates to all five aspects has become clear to all actors. For example, lessons learned in the past 'Integrated Conservation and Development' projects were (partially) learned in designs for subsequent 'Reducing Emissions from Deforestation and forest Degradation' (REDD+) efforts [122], and lessons learned in REDD+ pilots can inform current Forest Landscape Restoration efforts [123]. Policy reform in community forestry was more difficult to achieve then was expected, as the balance between visionary 'prophets', a practical profit orientation for the main stakeholders and the transparency requirements of 'prove it' agencies (within and outside of formal government, at local, national and international scales) is hard to achieve [124]. Long-term efforts to get operational programs to reduce emissions from deforestation and forest degradation (REDD+) have had much less success than expected, revealing complexities in implementing ideas that at first had large appeal [125].

Engagement in the Sumberjaya landscape in Indonesia, a hot spot of degradation and conflict around 2000 and an inspiration for watershed restoration and resolution of similar conflicts elsewhere went through three phases: first addressing tenure conflicts in the forest margins, then providing incentives for 'river-care' efforts to reduce sediment loads by engagement with the hydro-power company, and thirdly support for marketing environment-friendly products (especially coffee) through more rewarding channels [126].

A case study on restoring traditional water harvesting structures in India showed that groundwater recharge could indeed be enhanced, facilitating an extra crop and fruit tree production, while reducing the need for seasonal migration to a nearby urban center, but negative impacts on water capture by a downstream dam suggest that tradeoffs across scales are complex [127]. 
Some of the appearances of integrated approaches, however, may be informed by opportunities to tap into financial incentive streams that focus on specific entry points that represent current donor/investor priorities. Although many projects claim to be 'people-centric', their trust in specific 'theories of change' and publicly declared targets in terms of area or number of trees planted can be at odds with adaptive management and local control over process and speed.

\subsection{Land-Use Change as the Target of Interventions}

While land cover refers to the (bio)physical cover observed on the Earth's surface (FAO, 2005), land use is characterized by all "the arrangements, activities and inputs people undertake in a certain land cover type to produce, change or maintain it" [128-130]. As an important interface between 'actors' and 'land cover', the concept of 'land use' integrates social, economic and ecological aspects. It thus forms the target of restoration interventions. Only where land use is functional from a local perspective, restoration efforts, including land cover changes and changes in the ecosystem structure, will have a chance to be sustainable. Typologies of land use systems have to deal with life-cycle accounting, e.g., in swidden/fallow cycles, or rotational plantation or grazing management, and environmental impacts that are time-dependent.

Based on the level of land degradation, and the intended impact of restoration on land use and land-use changes, we suggest distinguishing here the following four intensities/levels of restoration:

- R.I. Ecological intensification: where improvements to the resource base are possible within existing land use by combining provisioning, regulating and regenerative aspects of agro-ecosystem functioning, within a context of supportive input and output markets. It may include a re-integration of livestock on farms that specialized into arable-only types of farming, as 'leys' as part of a rotation can be both productive and support the recovery of desirable soil properties.

- R.II Recovery/regeneration: where forms of fallow, resting land, exclosures from grazing, fire control and assisted natural regeneration can bring back conditions within which ecological intensification is possible. This level often entails a change in land use, at least temporarily.

- R.III Reparation/recuperation: where more intense action than recovery/regeneration is performed (e.g., tree planting), with additional external support, e.g., by creating access to nurseries for diversified germplasm, knowledge not locally available, inputs (including soil amendments) not currently used, supporting local institutions (and bridging social capital with institutions outside the landscape) not currently effective and/or changing tenurial relations with the state or private sector.

- R IV. Remediation: where past activities such as long-term unsustainable land use, mining, soil pollution or deep drainage have substantially or completely destroyed the ecosystem, preventing its natural functioning or its sustainable exploitation for forestry or agricultural production. This level requires intense specific, typically externally supported, and financed efforts and economic reparation of past damage, e.g., by those who benefited from the unsustainable resource exploitation.

The overarching goal of restoration is to progress across this restoration intensity scale down to the first level. In other words, the aim is to disrupt existing degradation spirals and transform lives and landscapes to bring them progressively back into the domain were 'ecological intensification' (R.I) becomes possible again.

The degree of needed intervention/support is likely to increase across the four levels, and so does the perimeter of the system and the reach of main institutions to be mobilized. Ecological intensification (R I) is generally applicable within the current local land use system at the farm or landscape scale. Recovery/regeneration (R II) within a local social-ecological system; reparation/recuperation (R III) within a broader national policy context; while remediation (R IV) usually requires a stronger external, or even international support and investment (Figure 7). 


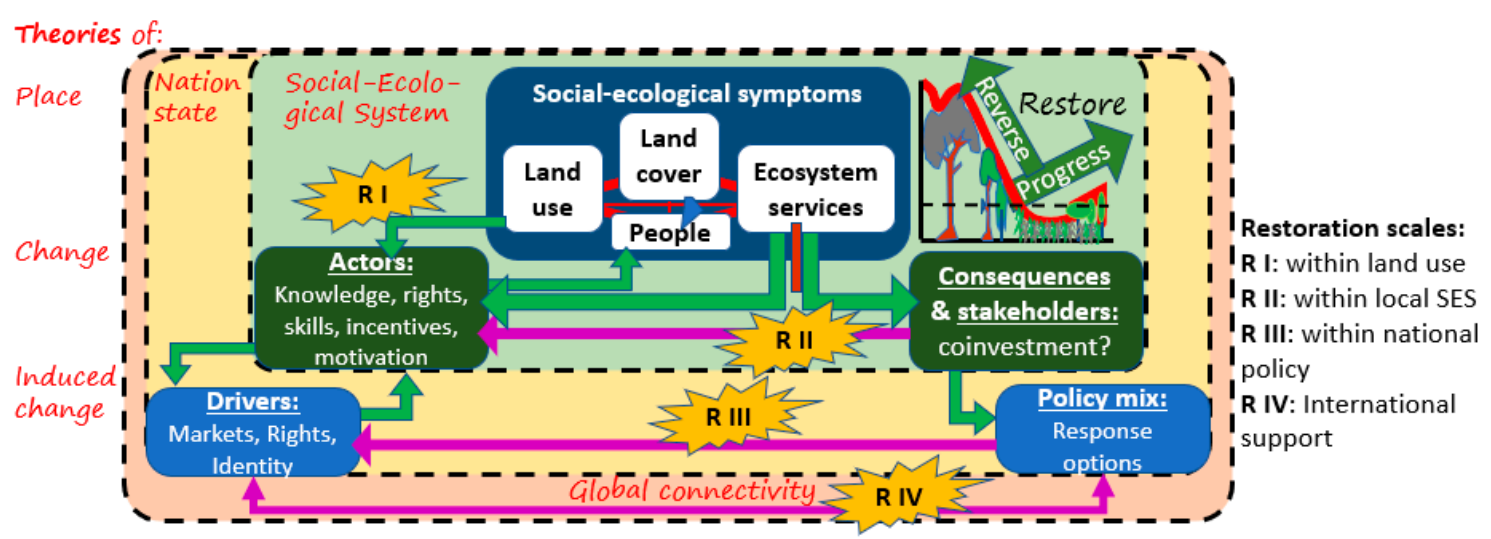

Figure 7. Four scales of restoration interventions and enabling actions in a nested social-ecological system perspective.

Enabling actions can be identified across these four levels that relate land use to current farm-gate profitability, additional local efforts to internalize externalities, changes in the national policy mix that influence the profitability of alternative land uses and allow sustainable land use planning and integrated landscape management, and/or global co-investment and efforts to address global challenges and strengthen global value chains. Responses at one scale (for example local SES) may help to 'scale up' to another scale, via pressures to national policies or international support, or by the cumulative effect to global drivers.

\subsection{Reconciling Bottom-Up and Top-Down Restoration Initiatives}

The strength of local motivation for change is probably the switch for any 'restoration' success, but often external support is needed to make change sustainable. Where 'restoration' is to be managed as a program or project, it requires 'metrics' as markers of progress and clarity on targets. To do so it needs to link bottom-up local initiatives and drives for return/increase of ecological functionality with the understanding of local social-ecological systems that are needed to define the elements of project designs that can attract funding and investment.

Some of the interventions targeting the surface soil structure (such as stone-rows, Zai pits and terracing in Sahelian agriculture [131]) are aimed at modifying lateral flows of soil and water in the landscape. Their effectiveness is likely to depend on scale and position on a topo-sequence, as they combine water harvesting source and sink zones. Physical interventions in surface soil structure tend to be labor demanding, with limited opportunities for mechanization, triggering a search for low-labor alternatives such as the naturally vegetated strips (started by not-plowing contour strips in intensively used slopes in the Philippines) as an alternative to tree planting and hedgerow pruning.

Local preferences are also an important aspect of obtaining the right mix between three primary ways of obtaining a change in land cover:

- Leave alone: rely on seed banks and seed rains (depending on the dispersal mode of (tree) seeds, distances to 'mother' trees, and presence of flying or walking animals as dispersal agents) as the basis of a diverse, locally adapted vegetation,

- Assisted/managed natural regeneration of vegetation or of land infrastructure: dealing with fire, grazing and other pressures and selective retention of desirable trees that can still derive from seedbanks and seed rain,

- Tree and grass planting, land infrastructure building: taking full control of the vegetation and infrastructures that will form the next land cover.

Especially a choice for the latter has important implications for local input markets, in terms of tree seeds and/or local nurseries that can provide diverse and good quality planting materials at an affordable cost. The widespread tendency to provide cost-free externally produced planting materials 
is now seen as a way to achieve short-term success (and project deliverables) at the cost of the long-term sustainability of solutions. Reconciling such with a gradual shift to lower intensities of restoration (toward the RI level) is important.

\subsection{Typology of Contexts}

Our typology of contexts ('theory of place') is based on the forest transition concept as applied to a pantropical dataset at the subwatershed level by Dewi et al. [108]. The classification relied primarily on (i) forest fraction, (ii) forest configuration (core, edge, and mosaic forest) and (iii) the logarithm of human population density. Stage 1 represents sub-basins where core forest covers around $80 \%$ of the total area of the sub-basins and population density is below $1 \mathrm{~km}^{-2}$. As population density increased, the fraction of core natural forest tended to decrease while the fraction of non-forest increased, and the ratio of planted to natural tree cover (both classified as forest in national statistics) increased. While some may envision a 'transition' to have distinct stages, in a large data set these are markers along a continuum of gradual change. In a parallel paper [132] the typology is applied to thirteen pantropical landscapes (from up-river Suriname in FT1 to densely polluted East Java in Indonesia in FT6, with key issues in the forest-water-people nexus identified for each landscape but changing in character. Generic aspects of degradation that occur across a range of forest transition stages are discussed elsewhere for a range of landscapes in Southeast Asia [118]: Forest classification conflicts in FT2-4, Over-intensified monocropping in FT3-5, Degraded hillslopes in FT3-6 and Fire-climax coarse-grass lands in FT3-6.

Beyond this general typology of contexts, six 'special places' have so far been identified that deserve specific attention in the analysis of pressures, drivers, and restoration options, because of their specific importance in the interactions between ecosystem functions and human activities:

Water towers-areas that generate river flow for neighboring landscapes but tend to have an above-average human population density and opportunities to supply local markets with vegetables and other commodities, as well as providing the highest quality types of coffee to global markets [108]. These are prominent in East and West Africa and various parts of Asia, often with substantial downstream areas depending on the rivers that originate in such water towers. They can include 'cloud forests' that capture moisture beyond what precipitation gauges register.

Riparian zone \& wetlands-As riparian zones often have fertile soils, sedimented from uphill erosion over long periods, offer easy ways of transport and access to water for irrigation and human use, as well as fishing as a complementary source of food security and nutrition, they have been the parts of the landscape with the longest settlement history in many parts of the world. Exceptions, with a ridge-based settlement pattern can be related to either prevalence of human disease vectors, or invading human enemies using the same river. Controlling disease vectors has often been a primary reason for draining wetlands, further allowing for increases in human population density. Many of the problem-solving interventions, however, displace pressures, such as the increase in downriver flood frequency if local flooding risk is reduced by increased drainage or removal of riparian vegetation that slowed down river flow. Restoring upstream water storage capacity and flow buffering is one of the primary targets of watershed restoration, but typically requires new upstream-downstream coordination of land use patterns and redistribution of economic benefits ('payments for ecosystem services').

Peat landscapes-Limited in area but now recognized in Congo and Amazon basin beyond their better-studied examples in Southeast Asia, they are disproportionately important in terrestrial carbon storage. Peat domes and lowland peat areas developed where drainage was restricted, and a year-round level of water saturation reduced organic matter decomposition to rates below the annual above- and belowground inputs [133]. Current understanding is that restoration focus should be on the peatland hydrological units (from dome to the river) essential for the continued function of peat domes including riparian zones that are not classified as peat soils themselves, spanning all land from river to river across the dome $[134,135]$. Beyond a 'zoning' perspective, focused on conservation of the dome, restoration should target the landscape, as human livelihoods in the riparian zone are 
both part of the problem (as the starting point for exploitation of the peat) and at the core of any livelihoods-focused solution.

Small islands, and mangroves in coastal zones-Small islands are miniature universes, where sectors of society are not as divergent as in larger on main-lands, even when national structures promote segregation. Small islands often have limited sources and supplies of freshwater, which is particularly challenging when tourism discovers the attraction of coastal zones and possibly adjacent coral reefs [136]. Developing tourism increases pressure on natural resources but may also provide a financial basis for restorative innovation, as seen in pioneering mangrove restoration on the tourist island Bali in Indonesia. Similar issues and opportunities to link terrestrial and marine ecosystems exist in the mangroves and other coastal vegetation of larger islands and continents. Attractive economic returns on mangrove destruction, e.g., for shrimp farming, as drivers of degradation affect the disproportionately high concentrations of people in coastal areas, exposing them to sea level rise, and surges due to typhoons and tsunami's [137-139].

Mining scars-areas where economic interests sparked particularly destructive change, especially where open-cast mining is used, leaving scars in the landscape where all vegetation and soil is disturbed to such a degree that natural recovery tends to be very slow. As there are frequently high metal concentrations in mine spoils affecting downstream water quality, remediating action is urgent [140]. While large-scale mining permits, and international pressure on transnational mining companies have 'internalized' such externalities by obligations to leave landscapes behind in a multifunctional condition, past mining and small and medium scale enterprises are not effectively bound by the same rules. External involvement in cleaning up the mess left by rogue mining companies can have a 'moral hazard' aspect, as the costs should morally be borne by those who benefited from the destruction.

Transport infrastructure-High investments in roads, canals and power lines make such, typically linear, landscape elements specifically vulnerable to floods, landslides, and similar disasters-to which they often contributed by disturbing hydrology and cutting into mountain slopes. As for the mines, engineers and constructors have a specific responsibility to avoid and mitigate such effects, but some of the past damage may require external 'restoration' support.

\subsection{A Typology of Restoration Intervention Options by Context}

Table 2 combines the two typologies developed in the previous sections (typology of contexts in Section 4.4; and typology of restoration options in Section 4.1), giving further specification at cell-level (possible options for a specific context), and identifying some among the special "hotspots".

Further descriptors of context that are likely to be relevant for restoration are the climatic zones (Figure 4A) and soil properties. Soil quality is a key context parameter for restoration: it is determined by soil type, texture and depth (as it relates to hydrology and erosion), topography (slope angle and length) and indicators of current soil condition relative to what could be expected for soil in a given location under undisturbed conditions, such as the ratios of current soil carbon and bulk density, to their reference values [141-143]. Such characteristics can be complemented by a characterization of the social, institutional, and economic context that often conditions both the drivers of degradation and the possibility to overcome them, often linking to goals. As the relations between tree cover, soil quality, and human population density within a given climatic zone are fairly strong, we can similarly identify areas where tree cover is above or below what would be expected for the same demographic condition (e.g., with a $10 \%$ bandwidth around the expected value). Further classification within the six columns for options are needed and can build on existing assessment methods and typologies for (gender-specific) rights, knowledge, and market access, and for ecosystem services and associated co-investment prototypes. 
Table 2. Proposed typology of restoration options by social-ecological context (with further distinctions by climate zone, human development index) and options for inducing change, with examples of intervention targets.

\begin{tabular}{|c|c|c|c|c|c|c|c|c|c|c|}
\hline \multirow[b]{2}{*}{ Context } & \multicolumn{10}{|c|}{ Interventions in Support of Any Combination of } \\
\hline & $\begin{array}{l}\text { Motivation, } \\
\text { Local } \\
\text { Insti-Tutions }\end{array}$ & \multicolumn{2}{|c|}{$\begin{array}{l}\text { Know-how } \\
\text { Tree Soil } \\
\text { Management }\end{array}$} & Rights & \multicolumn{2}{|c|}{$\begin{array}{c}\text { Markets } \\
\text { Inputs Outputs }\end{array}$} & \multicolumn{2}{|c|}{$\begin{array}{c}\text { Local ES, } \\
\text { Human Water } \\
\text { Health } \\
\end{array}$} & \multicolumn{2}{|c|}{$\begin{array}{c}\text { Teleconnections: } \\
\text { Climate Biodi- } \\
\text { versity }\end{array}$} \\
\hline SDG-links & $2,3,4,5,10,16$ & \multicolumn{2}{|c|}{$5,10,16$} & $4,5,8,17$ & \multicolumn{2}{|c|}{$1,2,8,9,12$} & \multicolumn{2}{|c|}{$3,6,7,11$} & \multicolumn{2}{|c|}{$13,1714,15,17$} \\
\hline $\begin{array}{l}\text { FT-stage1: } \\
\text { Core forests, low population } \\
\text { density, swiddening }\end{array}$ & & \multicolumn{2}{|l|}{ FGR } & & \multirow{6}{*}{$\begin{array}{l}\text { Nurseries, } \\
\text { Tree seed } \\
\text { sources }\end{array}$} & EcoT & \multirow{6}{*}{$\begin{array}{c}\text { Disease vector } \\
\text { control, clean } \\
\text { water supply, } \\
\text { sanitation }\end{array}$} & \multirow{6}{*}{$\begin{array}{c}\text { Water quantity, } \\
\text { regularity of flow } \\
\text { (floods/droughts), } \\
\text { quality }\end{array}$} & REDD+ & PA \\
\hline $\begin{array}{l}\text { FT-stage2: } \\
\text { e.g., Logged over forests, } \\
\text { swiddening }\end{array}$ & & \multicolumn{2}{|l|}{$\begin{array}{l}\text { FGR/RIL } \\
\text { /CBFM }\end{array}$} & & & $\begin{array}{l}\text { Logs } \\
\text { NTFP }\end{array}$ & & & REDD+ & PA \\
\hline $\begin{array}{c}\text { FT-stage3: } \\
\text { e.g., Mosaic of agriculture, } \\
\text { secondary forests, agroforests }\end{array}$ & $\begin{array}{l}\text { Local identity } \\
\text { and initiatives, } \\
\text { empowered and }\end{array}$ & $\begin{array}{l}\text { CBFM/ } \\
\mathrm{AF} / \mathrm{TGR}\end{array}$ & & $\begin{array}{l}\text { National law \& local } \\
\text { bylaw reform, forest } \\
\text { classification and land }\end{array}$ & & AFP, Plant & & & $\begin{array}{l}\text { REDD+/ } \\
\text { NDC }\end{array}$ & PA \\
\hline $\begin{array}{l}\text { Mosaic of agriculture, secondary } \\
\text { forests and plantations }\end{array}$ & $\begin{array}{l}\text { supported by } \\
\text { participation and } \\
\text { co-investment by }\end{array}$ & $\mathrm{AF} / \mathrm{TGR}$ & ISFM & use rights planning & & AFP, Plant & & & NDC & PA \\
\hline $\begin{array}{c}\text { FT-stage5: } \\
\text { Open-field agriculture } \\
\text { FT-stage6: }\end{array}$ & $\begin{array}{l}\text { external } \\
\text { stakeholders }\end{array}$ & $\mathrm{AF} / \mathrm{TGR}$ & ISFM & & & AFP & & & NDC & PA \\
\hline $\begin{array}{l}\text { Peri-urban, tree cover higher } \\
\text { than FT5 }\end{array}$ & & AF/TGR & & & & AFP & & & NDC & PA \\
\hline $\begin{array}{l}\text { Special places: } \\
\text { Water towers }\end{array}$ & & & & Water rights & & & & & & \\
\hline $\begin{array}{c}\text { Riparian zone \& wetlands } \\
\text { Peat }\end{array}$ & & Palud & Rewet & $\begin{array}{c}\text { RC } \\
\text { Drainage rights } \\
\text { RC }\end{array}$ & & & & & RC & \\
\hline $\begin{array}{c}\text { Small islands, Mangroves } \\
\text { Transport infrastructure } \\
\text { Mining scars }\end{array}$ & & & Land-slides & $\begin{array}{c}\text { Hotel permits } \\
\text { Development contracts } \\
\text { Permits, RC }\end{array}$ & & & & & & \\
\hline
\end{tabular}


As the option-by-context cells are mostly of a target 'land use' nature (see Figure 6 and Section 4.2), existing efforts to achieve generic classifications of land-use systems and intensity of land use, such as used and further developed in the ASB matrix studies can help [144,145]. Participatory land use planning methods and the LUMENS (land use for multiple environmental services) procedures are relevant here $[83,146]$.

\subsection{Discussion: Linking the Options in Context Typology to Issues and Goals Across Scales}

With a basic option-by-context typology (Table 2), we can revisit the links with an issue-and-goals level typology (as indicated in Figure 1B). Figure 8 suggests how the six critical enabling or resulting dimensions/aspects of degradation and restoration (earlier indicated as a social pentagon) relate across scales to the 17 sustainable development goals (SDGs). Most, if not all, goals relate to conditioning factors for restoration success (e.g., SDG16 on governance and rights, SDG4 on education or SDG5 and 10 on gender and generic equity), but also as policy domains that can benefit from the successful restoration of the land and livelihoods base of national economies. The challenge of coordinated approaches, however, exists within international organizations, as much as it does within national governments [147].

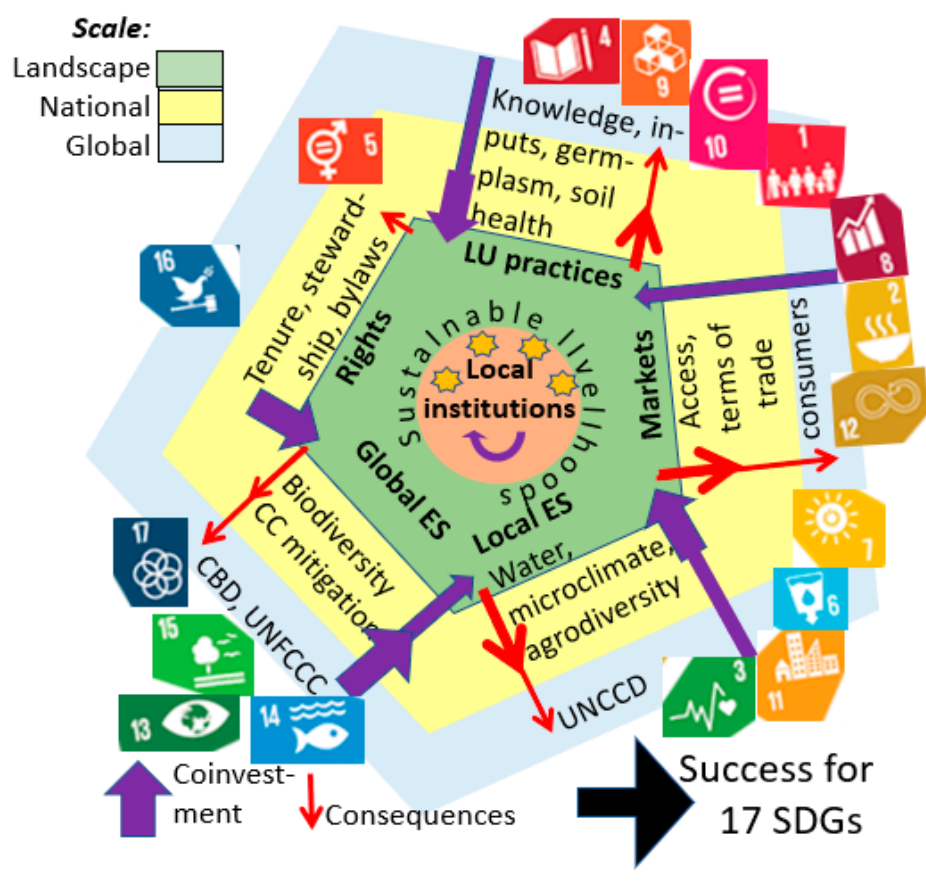

Figure 8. Cross-scale (local, national, global) linkage of the five determinants of local livelihoods, and the local institutional core needed to achieve the 17 sustainable development goals (SDGs).

Boundary work to relate the spheres of knowledge to the arenas of action [148] is needed to take steps from the 'symptoms' (Table 1) to potentially effective restoration actions (Table 2). Figure 9 suggests key researchable questions that can support a shared understanding among stakeholders of existing land users and use (who?, where?, how?), its consequences (so what?), stakeholders (who cares?) and the underlying drivers and pressures that need to be tackled (Why?), across scales (compare Figure 8). 


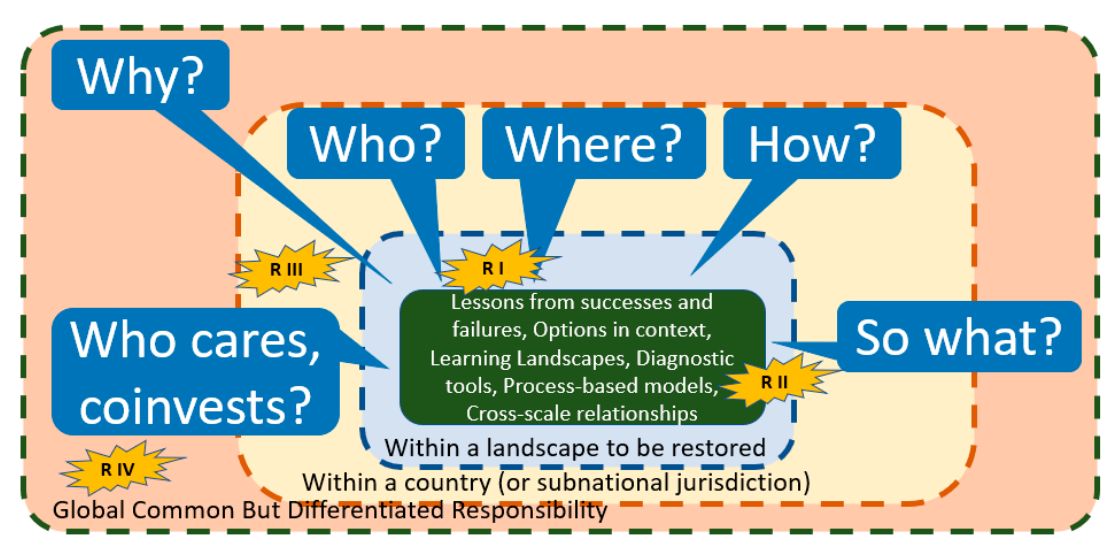

Figure 9. Questions that can drive efforts to understand theories of place and change for local social -ecological systems and their connections with higher-level pressures and drivers.

The boundary work to link existing and emerging knowledge to desirable action to make a difference on the ground has to recognize the different pace and dynamic of the five steps indicated in Figure 1B: A. Agenda setting (bridging between existing global and national 'restoration', 'climate change adaptation' or other 'sustainable development' initiatives), B. Better and shared understanding of what is at stake locally, but also in a wider (e.g., regional) perspective and how it interconnects with others, C. Commitment to common principles (e.g., specific targets within the SDG agenda and/or national development strategies, Nationally Determined Contributions to the Paris agreement on climate change, Aichi targets in the Convention on Biological Diversity (CBD)), D. Devolved details of design and delivery, dealing with trade-offs (what institutional change is needed to provide the essential context for change on the ground), and E. Efforts to evaluate and provide a basis for adjustments. Ten-point progress markers have been proposed for these steps [50].

Development of integrated policy responses [149] in the face of trade-offs [150],has to effectively deal with anticipating actor choices in response to proposed policies [151] and the diversity of opinions and interpretations of current system state, trends and leverage factors [152], including the balance between what can be locally achieved versus what is determined at national scale [153].

Finally, efforts can be presented as 'innovative restoration', strengthening the livelihoods dimension of existing restoration efforts, or as 'restorative innovation', supporting the integrative aspects of SDGs, pursuing restoration as an enabler (and co-benefit) of other key objectives. These are two sides of the same coin. International public-funded research programs such as FTA can support knowledge and implementation gaps in both aspects. Lessons learned from past research for development work in the restoration area suggests that a priority for future research investments is to co-develop with stakeholders system-level knowledge, combining pattern and process type understanding, to provide real solutions to actors on the ground, and the agility to answer to new, emerging issues.

\section{Conclusions}

Restoration is increasingly an object of interest for a multitude of institutional actors and groups of interests with specific objectives and perspectives as well as of diverse scientific disciplines and approaches. Each category of actors, each scientific approach has its own definition of restoration modeled by its specific perspective. This multiplicity of definitions, of ideal visions of what restoration should be is a significant impediment to collective, long-term engagement.

The typology presented in its paper can support a broader and more precise understanding of the very notion of restoration, in its diversity, generated by the diversity of contexts, objectives and solutions. Moreover, because it is precisely grounded on the interests, objectives and perspectives of the actors engaged in restoration it can help the diverse categories of actors to be involved understand the diversity of their objectives and find common ground uniquely adapted to the specificity of the situation. 
The following are some of the key points arising from the assessment and analysis presented in the study.

- There is no single generalizable approach to restoration despite the general notion underlying all restoration interventions is improving or rehabilitating the functionality of the system. Restoration involves multiple entry points most of which arise from either the state of the social-ecological systems or the choices of the people who depend on it.

- Despite the goal similarity (see point 1 above), the entry points to restoration also vary widely. The entry points are defined based on the specific contexts (both the place and its social-ecological aspects) of the system to be restored. It is thus important to understand how the identified entry point could lead to the desired state of the landscape or location and what benefits (e.g., ecosystem services) should be generated from the process of restoration for the effort to be characterized as being impactful.

- Progress along the recovery trajectory in a given landscape or location needs to embrace structural, functional, and social attributes all of which are required to form an agile system with its own improved structural, functional, and social 'identity' or characteristics.

- The typology proposed in this paper is a useful one in view of the lack of such structured interpretations of the typologies. It can support further studies on the effectiveness of interventions in different contexts.

- The framework can facilitate extrapolations from a single case, combining an intervention in a context, to other potential combinations. Such a framework can facilitate the establishment of sound research findings, public goods applicable in a diversity of cases, from a reduced number of well- studied cases in the long-term. This multiplication factor is particularly important given the length of restoration projects that increase both the time to observe results and the risks of non or bad intervention.

- Such a typology, grounded on the two axes of contexts and intervention options, can also orient comparative studies in order to support decision making. In particular, it could facilitate estimations ex-ante of costs and benefits, whether marketable or not, of a specific intervention in a specific context by comparison with past comparable interventions in comparable contexts. Such evidence-based estimations are necessary for actors to engage in long-term actions that are often disrupting established interests and to attract long-term investments of external actors, public and private.

- It is also important to move the restoration beyond the forest and agricultural systems and include the 'special' places of high social and ecological values. Such places may include water towers, riparian zone and wetlands, peat landscapes, small islands, and mangroves in coastal zones, mining scars and transport infrastructure. The global emphasis on greenhouse gases and food security has given generic forest and agricultural land issues high visibility in claims of tens or hundreds of Mha of restoration, while other critical ecosystems are not getting sufficient attention for their specific needs, which may imply higher costs per unit of land for greater societal benefits.

Author Contributions: Conceptualization, M.v.N., V.G. and P.A.M.; Investigation, M.v.N., S.D., B.L., L.D., N.P. and A.M.; Writing—original draft, M.v.N.; Writing—review \& editing, V.G., P.A.M., S.D., B.L., L.D., N.P. and A.M. All authors have read and agreed to the published version of the manuscript.

Funding: This research was funded by the CGIAR fund through the Forests, Trees and Agroforestry (FTA) program.

Acknowledgments: We acknowledge the ideas, reflections and inputs of many participants in Forests, Trees and Agroforestry (FTA) workshops held in August 2018 in Nairobi and January 2019 in Rome.

Conflicts of Interest: The authors declare no conflict of interest.

\section{References}

1. Available online: http://www.bonnchallenge.org (accessed on 18 July 2020).

2. Available online: http://forestdeclaration.org (accessed on 18 July 2020). 
3. Available online: https://www.decadeonrestoration.org/ (accessed on 18 July 2020).

4. Tomich, T.P.; Lidder, P.; Coley, M.; Gollin, D.; Meinzen-Dick, R.; Webb, P.; Carberry, P. Food and agricultural innovation pathways for prosperity. Agric. Syst. 2019, 172, 1-15. [CrossRef]

5. Gitz, V.; Place, F.; Koziell, I.; Pingault, N.; van Noordwijk, M.; Meybeck, A.; Minang, P. A Joint Stocktaking of CGIAR Work on Forest and Landscape Restoration; Working Paper 4; The CGIAR Research Program on Forests, Trees and Agroforestry (FTA): Bogor, Indonesia, 2020.

6. Katila, P.; Colfer, C.J.P.; de Jong, W.; Galloway, G.; Pacheco, P.; Winkel, G. (Eds.) Sustainable Development Goals: Their Impacts on Forests and People; Cambridge University Press: Cambridge, UK, 2019; p. 653.

7. Tidball, K.G. Seeing the forest for the trees: Hybridity and social-ecological symbols, rituals and resilience in postdisaster contexts. Ecol. Soc. 2014, 19, 25. [CrossRef]

8. Giono, J. The Man Who Planted Trees; Chelsea Green Publishing Co.: Chelsea, VT, USA, 1985.

9. Robbins, J. The Man Who Planted Trees: Lost Groves, Champion Trees, and an Urgent Plan to Save the Planet; Spiegel \& Grau Random House Group: New York, NY, USA, 2012.

10. McLauchlan, L. A multispecies collective planting trees: Tending to life and making meaning outside of the conservation heroic. Cult. Stud. Rev. 2019, 25, 135-153. [CrossRef]

11. Available online: https://www.nature.org/en-us/get-involved/how-to-help/plant-a-billion/ (accessed on 15 July 2020).

12. Available online: https://www.bbc.com/news/world-africa-50813726 (accessed on 15 July 2020).

13. Available online: https://en.wikipedia.org/wiki/Trillion_Tree_Campaign (accessed on 15 July 2020).

14. Crowther, T.W.; Glick, H.B.; Covey, K.R.; Bettigole, C.; Maynard, D.; Thomas, S.M.; Smith, J.R.; Hintler, G.; Duguid, M.C.; Amatulli, G.; et al. Mapping tree density at a global scale. Nature 2015, 525, 201. [CrossRef]

15. Creed. I.F.; van Noordwijk, M. Forests, trees and water on a changing planet: A contemporary scientific perspective. In Forest and Water on a Changing Planet: Vulnerability, Adaptation and Governance Opportunities: A Global Assessment Report (No. 38); Creed, I.F., van Noordwijk, M., Eds.; International Union of Forest Research Organizations (IUFRO): Vienna, Austria, 2018; pp. 13-24.

16. van Noordwijk, M.; Rahayu, S.; Gebrekirstos, A.; Kindt, R.; Tata, H.L.; Muchugi, A.; Ordonez, J.C.; Xu, J. Tree diversity as basis of agroforestry. In Sustainable Development Through Trees on Farms: Agroforestry in its Fifth Decade; van Noordwijk, M., Ed.; World Agroforestry (ICRAF): Bogor, Indonesia, 2019; pp. 17-44.

17. Available online: https://www.decadeonrestoration.org/Interactive/tree-planting-and-ecosystem-restorationcrash-course (accessed on 29 July 2020).

18. Garrity, D.P.; Bayala, J. Zinder: Farmer-managed natural regeneration of Sahelian parklands in Niger. In Sustainable Development Through Trees on Farms: Agroforestry in its Fifth Decade; van Noordwijk, M., Ed.; World Agroforestry (ICRAF): Bogor, Indonesia, 2019; pp. 151-172.

19. Duguma, L.A.; Minang, P.A.; Kimaro, A.A.; Otsyina, R.; Mpanda, M. Shinyanga: Blending old and new agroforestry to integrate development, climate change mitigation and adaptation in Tanzania. In Sustainable Development Through Trees on Farms: Agroforestry in its Fifth Decade; van Noordwijk, M., Ed.; World Agroforestry (ICRAF): Bogor, Indonesia, 2019; pp. 121-131.

20. van Noordwijk, M. (Ed.) Sustainable Development Through Trees on Farms: Agroforestry in its Fifth Decade; World Agroforestry (ICRAF): Bogor, Indonesia, 2019.

21. Miccolis, A.; Peneireiro, F.M.; Marques, H.R.; Vieira, D.L.M.; Arcoverde, M.F.; Hoffmann, M.R.; Rehder, T.; Pereira, A.V.B. Agroforestry Systems for Ecological Restoration: How to Reconcile Conservation and Production. Options for Brazil's Cerrado and Caatinga Biomes; Instituto Sociedade, População e Natureza-ISPN/World Agroforestry Centre (ICRAF): Brasília, Brasil, 2016; Available online: https:/www.worldagroforestry.org/ publication/agroforestry-systems-ecological-restoration-how-reconcile-conservation-and-production (accessed on 29 July 2020).

22. Cornelius, J.P.; Miccolis, A. Can market-based agroforestry germplasm supply systems meet the needs of forest landscape restoration? New For. 2018, 49, 457-469. [CrossRef]

23. HLPE. Agroecological and other innovative approaches for sustainable agriculture and food systems that enhance food security and nutrition. In A Report by the High Level Panel of Experts on Food Security and Nutrition of the Committee on World Food Security; FAO: Rome, Italy, 2019.

24. Shono, K.; Cadaweng, E.A.; Durst, P.B. Application of assisted natural regeneration to restore degraded tropical forestlands. Restor. Ecol. 2007, 15, 620-626. [CrossRef] 
25. Friday, K.S. Imperata Grassland Rehabilitation Using Agroforestry and Assisted Natural Regeneration; World Agroforestry Centre: Bogor, Indonesia, 1999.

26. Reij, C.; Garrity, D. Scaling up farmer-managed natural regeneration in Africa to restore degraded landscapes. Biotropica 2016, 48, 834-843. [CrossRef]

27. Chazdon, R.L.; Guariguata, M.R. Natural regeneration as a tool for large-scale forest restoration in the tropics: Prospects and challenges. Biotropica 2016, 48, 716-730. [CrossRef]

28. Perrow, M.R.; Davy, A.J. (Eds.) Handbook of Ecological Restoration; Cambridge University Press: Cambridge, UK, 2002; Volume 2.

29. Van Andel, J.; Aronson, J. Restoration Ecology; Blackwell Publishing: Malden, MA, USA, 2006.

30. Vaughn, K.J.; Porensky, L.M.; Wilkerson, M.L.; Balachowski, J.; Peffer, E.; Riginos, C.; Young, T.P. Restoration ecology. Nat. Educ. Knowl. 2010, 3, 66.

31. Clewell, A.; Rieger, J.; Munro, J. Guidelines for Developing and Managing Ecological Restoration Projects, 2nd ed.; Society for Ecological Restoration: Tucson, AZ, USA, 2005; Available online: http://c.ymcdn.com/sites/www.ser. org/resource/resmgr/custompages/publications/ser_publications/Dev_and_Mng_Eco_Rest_Proj.pdf (accessed on 29 July 2020).

32. Buckingham, K.; Weber, S. Assessing the ITTO Guidelines for the Restoration, Management, and Rehabilitation of Degraded Secondary Tropical Forests_-Case Studies of Ghana, Indonesia, and Mexico; International Tropical Tree Organization (ITTO) Consultancy with the World Resources Institute (WRI): Yokahama, Japan, 2015; Available online: http://www.itto.int/direct/topics/topics_pdf_download/topics_id=4632\&no=1 (accessed on 29 July 2020).

33. Stanturf, J.; Mansourian, S.; Kleine, M. (Eds.) Implementing Forest Landscape Restoration, A Practitioner's Guide; International Union of Forest Research Organizations, Special Programme for Development of Capacities (IUFRO-SPDC): Vienna, Austria, 2017; p. 128.

34. Chazdon, R.L.; Brancalion, P.H.; Lamb, D.; Laestadius, L.; Calmon, M.; Kumar, C. A policy-driven knowledge agenda for global forest and landscape restoration. Conserv. Lett. 2017, 10, 125-132. [CrossRef]

35. Clewell, A.F.; Aronson, J. Ecological Restoration: Principles, Values, and Structure of an Emerging Profession; Island Press: Washington, DC, USA, 2013.

36. Duguma, L.A.; Minang, P.A.; Mpanda, M.; Kimaro, A.; Alemagi, D. Landscape restoration from a socialecological system perspective? In Climate-Smart Landscapes: Multifunctionality in Practice; World Agroforestry Centre (ICRAF): Nairobi, Kenya, 2015; pp. 63-72.

37. Erbaugh, J.T.; Oldekop, J.A. Forest landscape restoration for livelihoods and well-being. Curr. Opin. Environ. Sustain. 2018, 32, 76-83. [CrossRef]

38. Kerr, J.; Verbist, B.; Suyanto; Pender, J. Placement of a payment for watershed services program in indonesia: Social and ecological factors. In Co-Investment in Ecosystem Services: Global Lessons from Payment and Incentive Schemes; Namirembe, S., Leimona, B., van Noordwijk, M., Minang, P., Eds.; World Agroforestry Centre (ICRAF): Nairobi, Kenya, 2017.

39. IUCN/WRI. A Guide to the Restoration Opportunities Assessment Methodology (ROAM): Assessing Forest Landscape Restoration Opportunities at the National or Sub-National Level; Working Paper (Road-test edition); IUCN: Gland, Switzerland, 2014; p. 125. Available online: http://www.bonnchallenge.org/content/restorationopportunities-assessment-methodology-roam (accessed on 29 July 2020).

40. Ghazoul, J.; Chazdon, R. Degradation and recovery in changing forest landscapes: A multiscale conceptual framework. Annu. Rev. Environ. Resour. 2017, 42, 161-188. [CrossRef]

41. de Souza, S.E.F.; Vidal, E.; Chagas, G.D.F.; Elgar, A.T.; Brancalion, P.H. Ecological outcomes and livelihood benefits of community-managed agroforests and second growth forests in Southeast Brazil. Biotropica 2016, 48, 868-881. [CrossRef]

42. Baynes, J.; Herbohn, J.; Smith, C.; Fisher, R.; Bray, D. Key factors which influence the success of community forestry in developing countries. Glob. Environ. Chang. 2015, 35, 226-238. [CrossRef]

43. HLPE. Sustainable Forestry for Food Security and Nutrition: A Report by the High-Level Panel of Experts on Food Security and Nutrition of the Committee on World Food Security; FAO: Rome, Italy, 2017; Available online: http://www.fao.org/3/a-i7395e.pdf (accessed on 29 July 2020).

44. IRP. Land Restoration for Achieving the Sustainable Development Goals: An International Resource Panel Think Piece; Herrick, J.E., Abrahamse, T., Abhilash, P.C., Ali, S.H., Alvarez-Torres, P., Barau, A.S., Branquinho, C., Chhatre, A., Chotte, J.L., Von Maltitz, G.P., Eds.; United Nations Environment Programme: Nairobi, Kenya, 2019. 
45. Besseau, P.; Graham, S.; Christophersen, T. Restoring Forests and Landscapes: The Key to a Sustainable Future; IUFRO On Behalf of the Global Partnership on Forest and Landscape Restoration: Vienna, Austria, 2018.

46. Chazdon, R.L.; Wilson, S.J.; Brondizio, E.; Guariguata, M.R.; Herbohn, J. Key challenges for governing forest and landscape restoration across different contexts. Land Use Policy 2020, 104854. [CrossRef]

47. Chazdon, R.L.; Gutierrez, V.; Brancalion, P.H.; Laestadius, L.; Guariguata, M.R. Co-creating conceptual and working frameworks for implementing forest and landscape restoration based on core principles. Forests 2020, 11, 706. [CrossRef]

48. Djenontin, I.N.S.; Zulu, L.C.; Ligmann-Zielinska, A. Improving representation of decision rules in LUCC-ABM: An example with an elicitation of farmers' decision making for landscape restoration in central malawi. Sustainability 2020, 12, 5380. [CrossRef]

49. Lee, D.R.; Barrett, C.B. (Eds.) Tradeoffs or Synergies? Agricultural Intensification, Economic Development, and the Environment; CABI: Wallingford, UK, 2000; p. 538.

50. van Noordwijk, M. Integrated natural resource management as pathway to poverty reduction: Innovating practices, institutions and policies. Agric. Syst. 2019, 172, 60-71. [CrossRef]

51. Jackson, L.; van Noordwijk, M.; Bengtsson, J.; Foster, W.; Lipper, L.; Pulleman, M.; Said, M.; Snaddon, J.; Vodouhe, R. Biodiversity and agricultural sustainagility: From assessment to adaptive management. Curr. Opin. Environ. Sustain. 2010, 2, 80-87. [CrossRef]

52. Rockström, J.; Steffen, W.; Noone, K.; Persson, Å.; Chapin, F.S.; Lambin, E.; Lenton, T.M.; Scheffer, M.; Folke, C.; Schellnhuber, H.J. Planetary boundaries: Exploring the safe operating space for humanity. Ecol. Soc. 2009, 14, 1-33. [CrossRef]

53. Rockström, J.; Falkenmark, M.; Allan, T.; Folke, C.; Gordon, L.; Jägerskog, A.; Kummu, M.; Lannerstad, M. The unfolding water drama in the Anthropocene: Towards a resilience-based perspective on water for global sustainability. Ecohydrology 2014, 7, 1249-1261. [CrossRef]

54. van Noordwijk, M.; Bargues-Tobella, A.; Muthuri, C.W.; Gebrekirstos, A.; Maimbo, M.; Leimona, B.; Bayala, J.; Ma, X.; Lasco, R.; Xu, J.; et al. Agroforestry as part of nature-based water management. In Sustainable Development through Trees on Farms: Agroforestry in its Fifth Decade; van Noordwijk, M., Ed.; World Agroforestry (ICRAF): Bogor, Indonesia, 2019; pp. 305-334.

55. Sayer, J.; Sunderland, T.; Ghazoul, J.; Pfund, J.-L.; Sheil, D.; Meijaard, E.; Venter, M.; Boedhihartono, A.K.; Day, M.; Garcia, C.; et al. Ten principles for a landscape approach to reconciling agriculture, conservation, and other competing land uses. Proc. Natl. Acad. Sci. USA 2013, 110, 8349-8356. [CrossRef] [PubMed]

56. Freeman, O.E.; Duguma, L.A.; Minang, P.A. Operationalizing the integrated landscape approach in practice. Ecol. Soc. 2015, 20, 24. Available online: http://www.ecologyandsociety.org/vol20/iss1/art24/ (accessed on 29 July 2020). [CrossRef]

57. Minang, P.A.; van Noordwijk, M.; Freeman, O.E.; Mbow, C.; de Leeuw, J.; Catacutan, D. (Eds.) Climate-Smart Landscapes: Multifunctionality In Practice; World Agroforestry Centre (ICRAF): Nairobi, Kenya, 2015; p. 444. ISBN 978-92-9059-375-1. Available online: http://asb.cgiar.org/climate-smart-landscapes/ (accessed on 29 July 2020).

58. Reed, J.; van Vianen, J.; Deakin, E.L.; Barlow, J.; Sunderland, T. Integrated landscape approaches to managing social and environmental issues in the tropics: Learning from the past to guide the future. Glob. Chang. Biol. 2016, 22, 2540-2554. [CrossRef]

59. Sayer, J.; Margules, C.; Boedhihartono, A.K.; Sunderland, T.; Langston, J.D.; Reed, J.; Riggs, R.A.; Buck, L.E.; Campbell, B.M.; Kusters, K.; et al. Measuring the effectiveness of landscape approaches to conservation and development. Sustain. Sci. 2016, 12, 465-476. [CrossRef]

60. Wilson, S.J.; Cagalanan, D. Governing restoration: Strategies, adaptations and innovations for tomorrow's forest landscapes. World Dev. Perspect. 2016, 4, 11-15. [CrossRef]

61. Evans, K.A.; Guariguata, M.R. Success from the ground up: Participatory monitoring and forest restoration. In Occasional Paper 159; Center for International Forestry Research (CIFOR): Bogor, Indonesia, 2016. Available online: http://www.cifor.org/publications/pdf_fies/OccPapers/OP-159.pdf (accessed on 20 July 2020).

62. FAO. Global Guidelines for the Restoration of Degraded Forests and Landscapes in Drylands: Building Resilience and Benefiting Livelihoods; FAO Forestry Paper 175; Food and Agricultural Organization of the United Nations: Rome, Italy, 2015; Available online: http://www.fao.org/3/a-i5036e.pdf (accessed on 20 July 2020). 
63. Bozzano, M.; Jalone, R.; Thomas, E.; Boschier, D.; Gallo, L.; Cavers, S.; Bordacs, S.; Smith, P.; Loo, J. (Eds.) Genetic Considerations in Ecosystem Restoration Using Native Tree Species; FAO and Bioversity International: Rome, Italy, 2014; Available online: http://www.fao.org/3/a-i3938e.pdf (accessed on 29 July 2020).

64. Dawson, I.K.; Leakey, R.; Clement, C.R.; Weber, J.C.; Cornelius, J.P.; Roshetko, J.M.; Vinceti, B.; Kalinganire, A.; Tchoundjeu, Z.; Masters, E.; et al. The management of tree genetic resources and the livelihoods of rural communities in the tropics: Non-timber forest products, smallholder agroforestry practices and tree commodity crops. For. Ecol. Manag. 2014, 333, 9-21. [CrossRef]

65. Jalonen, R.; Valette, M.; Boshier, D.; Duminil, J.; Thomas, E. Forest and landscape restoration severely constrained by a lack of attention to the quantity and quality of tree seed: Insights from a global survey. Conserv. Lett. 2018, 11, e12424. [CrossRef]

66. Sinclair, F.L.; Coe, R. The options by context approach: A paradigm shift in agronomy. Exp. Agric. 2019, 55, 1-13. [CrossRef]

67. van Noordwijk, M.; Coe, R. Methods in agroforestry research across its three paradigms. In Sustainable Development Through Trees on Farms: Agroforestry in Its Fifth Decade; van Noordwijk, M., Ed.; World Agroforestry (ICRAF): Bogor, Indonesia, 2019; pp. 379-402.

68. Mithöfer, D.; van Noordwijk, M.; Leimona, B.; Cerutti, P.O. Certify and shift blame, or resolve issues? Environmentally and socially responsible global trade and production of timber and tree crops. Int. J. Biodivers. Sci. Ecosyst. Serv. Manag. 2017, 13, 72-85. [CrossRef]

69. Leimona, B.; van Noordwijk, M.; Mithöfer, D.; Cerutti, P.O. Environmentally and socially responsible global production and trade of timber and tree crop commodities: Certification as a transient issue-attention cycle response to ecological and social issues. Int. J. Biodivers. Sci. Ecosyst. Serv. Manag. 2018, 13, 497-502. [CrossRef]

70. van Noordwijk, M.; Dewi, S.; Minang, P.A.; Simons, A.J. Deforestation-free claims: Scams or substance? In Zero Deforestation: A Commitment to Change; Pasiecznik, N., Savenije, H., Eds.; Tropenbos International: Wageningen, The Netherlands, 2017; pp. 11-16.

71. Creed, I.F.; van Noordwijk, M. (Eds.) Forest and Water on a Changing Planet: Vulnerability, Adaptation and Governance Opportunities: A Global Assessment Report (No. 38); International Union of Forest Research Organizations (IUFRO): Vienna, Austria, 2018.

72. Harris, J.A.; Hobbs, R.J.; Higgs, E.; Aronson, J. Ecological restoration and global climate change. Restor. Ecol. 2006, 14, 170-176. [CrossRef]

73. Meli, P.; Holl, K.D.; Benayas, J.M.R.; Jones, H.P.; Jones, P.C.; Montoya, D.; Mateos, D.M. A global review of past land use, climate, and active vs. passive restoration effects on forest recovery. PLoS ONE 2017, 12, e0171368. [CrossRef] [PubMed]

74. Mansourian, S.; Dudley, N.; Vallauri, D. Forest landscape restoration: Progress in the last decade and remaining challenges. Ecol. Restor. 2017, 35, 281-288. [CrossRef]

75. Swinfield, T.; Afriandi, R.; Antoni, F.; Harrison, R.D. Accelerating tropical forest restoration through the selective removal of pioneer species. For. Ecol. Manag. 2016, 381, 209-216. [CrossRef]

76. Harrison, R.D.; Tan, S.; Plotkin, J.B.; Slik, F.; Detto, M.; Brenes, T.; Itoh, A.; Davies, S.J. Consequences of defaunation for a tropical tree community. Ecol. Lett. 2013, 16, 687-694. [CrossRef]

77. de Royer, S.; van Noordwijk, M.; Roshetko, J. Does community-based forest management in Indonesia devolve social justice or social costs? Int. For. Rev. 2018, 20, 167-180. [CrossRef]

78. van Noordwijk, M.; Leimona, B. Principles for fairness and efficiency in enhancing environmental services in Asia: Payments, compensation, or co-investment? Ecol. Soc. 2010, 15, 17. [CrossRef]

79. Leimona, B.; van Noordwijk, M.; de Groot, R.; Leemans, R. Fairly efficient, efficiently fair: Lessons from designing and testing payment schemes for ecosystem services in Asia. Ecosyst. Serv. 2015, 12, 16-28. [CrossRef]

80. Namirembe, S.; Leimona, B.; van Noordwijk, M.; Minang, P.A. Co-Investment in Ecosystem Services: Global Lessons from Payment and Incentive Schemes; World Agroforestry (ICRAF): Nairobi, Kenya, 2017; Chapter 1; Available online: https://www.worldagroforestry.org/sites/default/files/u884/Ch1_IntroCoinvest_ebook.pdf (accessed on 20 July 2020).

81. Meinzen-Dick, R.; Quisumbing, A.; Doss, C.; Theis, S. Women's land rights as a pathway to poverty reduction: Framework and review of available evidence. Agric. Syst. 2017, 172, 72-82. [CrossRef]

82. Kusters, K.; Buck, L.; de Graaf, M.; Minang, P.A.; van Oosten, C.; Zagt, R. Participatory planning, monitoring and evaluation of multi-stakeholder platforms in integrated landscape initiatives. Environ. Manag. 2017, 2, 170-181. [CrossRef] [PubMed] 
83. van Noordwijk, M.; Kim, Y.S.; Leimona, B.; Hairiah, K.; Fisher, L.A. Metrics of water security, adaptive capacity and agroforestry in Indonesia. Curr. Opin. Environ. Sustain. 2016, 21, 1-8. [CrossRef]

84. Ahrends, A.; Hollingsworth, P.M.; Beckschäfer, P.; Chen, H.; Zomer, R.J.; Zhang, L.; Wang, M.; Xu, J. China's fight to halt tree cover loss. Proc. R. Soc. B 2017, 284. [CrossRef]

85. Wangpakapattanawong, P.; Kavinchan, N.; Vaidhayakarn, C.; Schmidt-Vogt, D.; Elliott, S. Fallow to forest: Applying indigenous and scientific knowledge of swidden cultivation to tropical forest restoration. For. Ecol. Manag. 2010, 260, 1399-1406. [CrossRef]

86. Chirwa, P.W.; Mahamane, L. Overview of restoration and management practices in the degraded landscapes of the Sahelian and dryland forests and woodlands of East and southern Africa. South. For. J. For. Sci. 2017, 79, 87-94. [CrossRef]

87. Mokria, M.; Tolera, M.; Sterck, F.J.; Gebrekirstos, A.; Bongers, F.; Decuyper, M.; Sass-Klaassen, U. The frankincense tree Boswellia neglecta reveals high potential for restoration of woodlands in the Horn of Africa. For. Ecol. Manag. 2017, 385, 16-24. [CrossRef]

88. Miccolis, A. Restoration through agroforestry: Options for reconciling livelihoods with conservation in the cerrado and caatinga biomes in Brazil. Exp. Agric. 2017, 55, 208-225. [CrossRef]

89. Gann, G.D.; McDonald, T.; Walder, B.; Aronson, J.; Nelson, C.R.; Jonson, J.; Hallett, J.G.; Eisenberg, C.; Guariguata, M.R.; Liu, J.; et al. International principles and standards for the practice of ecological restoration. Second edition. Restor. Ecol. 2019, 27, S1-S46. [CrossRef]

90. IPBES. The IPBES Assessment Report on Land Degradation And Restoration; Montanarella, L., Scholes, R., Brainich, A., Eds.; Secretariat of the Intergovernmental Science-Policy Platform on Biodiversity and Ecosystem Services: Bonn, Germany, 2018; p. 44. Available online: https://ipbes.net/sites/default/files/2018_ldr_full_ report_book_v4_pages.pdf (accessed on 29 July 2020).

91. Available online: https://www.iucn.org/theme/forests/our-work/forest-landscape-restoration (accessed on 29 July 2020).

92. Millennium Ecosystem Assessment. Ecosystems and Human Well-Being: Current State and Trends; Island Press: Washington, DC, USA, 2005; Volume 5.

93. Available online: https://www.iucn.org/news/protected-areas/201905/enhancing-progress-towards-aichitarget-11\#: \{\}:text=As\%20reported \%20in \%20the \%20latest, and \%2010\%25\%20of\%20the \%20sea.\&text=In\% 20an\%20effort\%20to\%20ramp,Partnership\%20on\%20Aichi\%20Target\%2011 (accessed on 18 July 2020).

94. Potschin-Young, M.; Haines-Young, R.; Görg, C.; Heink, U.; Jax, K.; Schleyer, C. Understanding the role of conceptual frameworks: Reading the ecosystem service cascade. Ecosyst. Serv. 2018, 29, 428-440. [CrossRef]

95. Van Noordwijk, M.; Minang, P.A. If We Cannot Define It, We Cannot Save It: Forest Definitions and REDD; Tropenbos International: Wageningen, The Netherlands, 2009.

96. Chazdon, R.L.; Brancalion, P.H.; Laestadius, L.; Bennett-Curry, A.; Buckingham, K.; Kumar, C.; Wilson, S.J. When is a forest a forest? Forest concepts and definitions in the era of forest and landscape restoration. Ambio 2016, 45, 538-550. [CrossRef]

97. Dignac, M.F.; Derrien, D.; Barré, P.; Barot, S.; Cécillon, L.; Chenu, C.; Chevallier, T.; Freschet, G.T.; Garnier, P.; Guenet, B.; et al. Increasing soil carbon storage: Mechanisms, effects of agricultural practices and proxies. A review. Agron. Sustain. Dev. 2017, 37, 14. [CrossRef]

98. Suprayogo, D.; van Noordwijk, M.; Hairiah, K.; Meilasari, N.; Rabbani, A.L.; Ishaq, R.M.; Widianto, W. Infiltration-Friendly Agroforestry Land Uses on Volcanic Slopes in the Rejoso Watershed, East Java, Indonesia. Land 2020, 9, 240. [CrossRef]

99. Shepherd, K.D.; Shepherd, G.; Walsh, M.G. Land health surveillance and response: A framework for evidenceinformed land management. Agric. Syst. 2015, 132, 93-106. [CrossRef]

100. Tomich, T.P.; Chomitz, K.; Francisco, H.; Izac, A.M.N.; Murdiyarso, D.; Ratner, B.D.; Thomas, D.E.; van Noordwijk, M. Policy analysis and environmental problems at different scales: Asking the right questions. Agric. Ecosyst. Environ. 2004, 104, 5-18. [CrossRef]

101. Namirembe, S.; Leimona, B.; van Noordwijk, M.; Minang, P.A. Co-Investment in Ecosystem Services: Global Lessons from Payment and Incentive Schemes; World Agroforestry (ICRAF): Nairobi, Kenya, 2019.

102. van Noordwijk, M.; Duguma, L.A.; Dewi, S.; Leimona, B.; Catacutan, D.M.; Lusiana, B.; Öborn, I.; Hairiah, K.; Minang, P.A. SDG synergy between agriculture and forestry in the food, energy, water and income nexus: Reinventing agroforestry? Curr. Opin. Environ. Sustain. 2018, 34, 33-42. [CrossRef] 
103. Minang, P.A.; van Noordwijk, M.; Duguma, L.A. Policies for ecosystem services enhancement. In Sustainable Development Through Trees on Farms: Agroforestry in its Fifth Decade; van Noordwijk, M., Ed.; World Agroforestry (ICRAF): Bogor, Indonesia, 2019; pp. 361-376.

104. Rudel, T.K. Did a green revolution restore the forests of the American South. In Agricultural Technologies and Tropical Deforestation; Angelsen, A., Kaimowitz, D., Eds.; CABi: Wallingford, UK, 2001; pp. 53-68.

105. Minang, P.A.; van Noordwijk, M.; Kahurani, E. Partnership in the Tropical Forest Margins: A 20-Year Journey in Search of Alternatives to Slash-and-Burn; World Agroforestry: Nairobi, Kenya, 2014; p. 241.

106. Li, S.; Li, X. Global understanding of farmland abandonment: A review and prospects. J. Geogr. Sci. 2017, 27, 1123-1150. [CrossRef]

107. Schröder, P.; Antonarakis, A.S.; Brauer, J.; Conteh, A.; Kohsaka, R.; Uchiyama, Y.; Pacheco, P. SDG 12: Responsible consumption and production-Potential Benefits and impacts on forests and livelihoods. In Sustainable Development Goals: Their Impacts on Forests and People; Katila, P., Colfer, C.J.P., de Jong, W., Galloway, G., Pacheco, P., Winkel, G., Eds.; Cambridge University Press: Cambridge, UK, 2019; pp. 386-418.

108. Dewi, S.; van Noordwijk, M.; Zulkarnain, M.T.; Dwiputra, A.; Prabhu, R.; Hyman, G.; Gitz, V.; Nasi, R. Tropical forest-transition landscapes: A portfolio for studying people, tree crops and agro-ecological change in context. Int. J. Biodivers. Sci. Ecosyst. Serv. Manag. 2017, 13, 312-329. [CrossRef]

109. Filoso, S.; Bezerra, M.O.; Weiss, K.C.; Palmer, M.A. Impacts of forest restoration on water yield: A systematic review. PLoS ONE 2017, 12, e0183210. [CrossRef]

110. Ilstedt, U.; Tobella, A.B.; Bazié, H.R.; Bayala, J.; Verbeeten, E.; Nyberg, G.; Sanou, J.; Benegas, L.; Murdiyarso, D.; Laudon, H.; et al. Intermediate tree cover can maximize groundwater recharge in the seasonally dry tropics. Sci. Rep. 2016, 6. [CrossRef]

111. van Noordwijk, M.; Tanika, L.; Lusiana, B. Flood risk reduction and flow buffering as ecosystem servicesPart I: Theory on a flow persistence indicator. Hydrol. Earth Syst. Sci. 2017, 21, 2321-2340. [CrossRef]

112. van Noordwijk, M.; Tanika, L.; Lusiana, B. Flood risk reduction and flow buffering as ecosystem services-Part II: Land use and rainfall intensity effects in Southeast Asia. Hydrol. Earth Syst. Sci. 2017, 21, 2341-2360. [CrossRef]

113. Dufour, S.; Piégay, H. From the myth of a lost paradise to targeted river restoration: Forget natural references and focus on human benefits. River Res. Appl. 2009, 25, 568-581. [CrossRef]

114. Ellison, D.; Morris, C.; Locatelli, B.; Sheil, D.; Cohen, J.D.M.; Murdiyarso, D.; Gutierrez, V.; Van Noordwijk, M.; Creed, I.F.; Pokorny, J.; et al. Trees, forests and water: Cool insights for a hot world. Glob. Environ. Chang. 2017, 43, 51-61. [CrossRef]

115. Bonnesoeur, V.; Locatelli, B.; Guariguata, M.R.; Ochoa-Tocachi, B.F.; Vanacker, V.; Mao, Z.; Stokes, A.; Mathez-Stiefel, S.L. Impacts of forests and forestation on hydrological services in the Andes: A systematic review. For. Ecol. Manag. 2019, 433, 569-584. [CrossRef]

116. Sternberg, L.D. Savanna-forest hysteresis in the tropics. Glob. Ecol. Biogeogr. 2001, 10, 369-378. [CrossRef]

117. Hirota, M.; Holmgren, M.; Van Nes, E.H.; Scheffer, M. Global resilience of tropical forest and savanna to critical transitions. Science 2011, 334, 232-235. [CrossRef]

118. van Noordwijk, M.; Ekadinata, A.; Leimona, B.; Catacutan, D.C.; Martini, E.; Tata, H.L.; Öborn, I.; Hairiah, K.; Wangpakapattanawong, P.; Mulia, R.; et al. Agroforestry Options for Degraded Landscapes in Southeast Asia; Dagar, J.C., Gupta, S.R., Teketay, D., Eds.; Agroforestry for Degraded Landscapes Springer: Singapore, 2020; in press.

119. Leimona, B.; van Noordwijk, M.; Kennedy, S.; Namirembe, S.; Minang, P.A. Synthesis and lessons on ecological, economic, social and governance propositions. In Co-Investment in Ecosystem Services: Global Lessons from Payment and Incentive Schemes; Namirembe, S., Leimona, B., van Noordwijk, M., Minang, P.A., Eds.; World Agroforestry Centre (ICRAF): Nairobi, Kenya, 2019; Chapter 38.

120. Van Noordwijk, M.; Leimona, B.; Jindal, R.; Villamor, G.B.; Vardhan, M.; Namirembe, S.; Catacutan, D.; Kerr, J.; Minang, P.A.; Tomich, T.P. Payments for Environmental Services: Evolution toward efficient and fair incentives for multifunctional landscapes. Annu. Rev. Environ. Resour. 2012, 37, 389-420. [CrossRef]

121. Chapman, M.; Satterfield, T.; Wittman, H.; Chan, K.M. A payment by any other name: Is Costa Rica's PES a payment for services or a support for stewards? World Dev. 2020, 129, 104900. [CrossRef]

122. Minang, P.A.; van Noordwijk, M. Design challenges for achieving reduced emissions from deforestation and forest degradation through conservation: Leveraging multiple paradigms at the tropical forest margins. Land Use Policy 2013, 31, 61-70. [CrossRef]

123. Barr, C.M.; Sayer, J.A. The political economy of reforestation and forest restoration in Asia-Pacific: Critical issues for REDD+. Biol. Cons. 2012, 154, 9-19. [CrossRef] 
124. van Noordwijk, M. Prophets, profits, prove it: Social forestry under pressure. One Earth 2020, 2, 394-397. [CrossRef]

125. Minang, P.A.; Van Noordwijk, M.; Duguma, L.; Alemagi, D.; Do, T.H.; Bernard, F.; Agung, P.; Robiglio, V.; Catacutan, D.; Suyanto, S.; et al. REDD+ Readiness progress across countries: Time for reconsideration. Clim. Policy 2014, 14, 685-708. [CrossRef]

126. van Noordwijk, M.; Leimona, B.; Amaruzaman, S. Sumber Jaya from conflict to source of wealth in Indonesia: Reconciling coffee agroforestry and watershed functions. In Sustainable Development Through Trees on Farms: Agroforestry in its Fifth Decade; van Noordwijk, M., Ed.; World Agroforestry (ICRAF): Bogor, Indonesia, 2019; pp. 177-192.

127. Singh, R.; van Noordwijk, M.; Chaturvedi, O.P.; Garg, K.K.; Dev, I.; Wani, S.P.; Rizvi, J. Bundelkhand: Public co-investment in groundwater recharge in India. In Sustainable Development Through Trees on Farms: Agroforestry in its Fifth Decade; van Noordwijk, M., Ed.; World Agroforestry (ICRAF): Bogor, Indonesia, 2019; pp. 201-208.

128. FAO/UNEP. Terminology for Integrated Resources Planning and Management; United Nations Environmental Programme: Kenya, Nairobi; FAO: Rome, Italy, 1999.

129. FAO. Land Cover Classification System Classification Concepts and User Manual Software Version (2); Di Gregorio, A., Jansen, L.J.M., Eds.; FAO: Rome, Italy, 2005; Available online: http://www.fao.org/3/y7220e/y7220e00.htm (accessed on 20 July 2020).

130. FAO/ITPS. Status of the World's Soil Resources (SWSR)—Main Report; Food and Agriculture Organization of the United Nations and Intergovernmental Technical Panel on Soils: Rome, Italy, 2015; p. 650. Available online: http://www.fao.org/3/a-i5199e.pdf (accessed on 20 July 2020).

131. Bayala, J.; Sanou, J.; Teklehaimanot, Z.; Ouedraogo, S.J.; Kalinganire, A.; Coe, R.; Van Noordwijk, M. Advances in knowledge of processes in soil-tree-crop interactions in parkland systems in the West African Sahel: A review. Agric. Ecosyst. Environ. 2015, 205, 25-35. [CrossRef]

132. van Noordwijk, M.; Speelman, E.; Hofstede, G.J.; Farida, A.; Abdurrahim, A.Y.; Miccolis, A.; Hakim, A.L.; Wamucii, C.N.; Lagneaux, E.; Andreotti, F.; et al. Sustainable agroforestry management: Changing the game. Land 2020, 9, 243. [CrossRef]

133. Saragi-Sasmito, M.F.; Murdiyarso, D.; June, T.; Sasmito, S.D. Carbon stocks, emissions, and aboveground productivity in restored secondary tropical peat swamp forests. Mitig. Adapt. Strat. Glob. Chang. 2018, 24, 521-533. [CrossRef]

134. Widayati, A.; Tata, H.L.; van Noordwijk, M. Agroforestry in peatlands: Combining productive and protective functions as part of restoration. In Agroforestry Options for ASEAN Series No. 4; World Agroforestry Centre (ICRAF): Bogor, Indonesia, 2016.

135. van Noordwijk, M.; Matthews, R.B.; Agus, F.; Farmer, J.; Verchot, L.; Hergoualc'h, K.; Persch, S.; Tata, H.L.; Lusiana, B.; Widayati, A.; et al. Mud, muddle and models in the knowledge value- chain to action on tropical peatland issues. Mitig. Adapt. Strat. Glod. Chang. 2014, 19, 863-885.

136. van Noordwijk, M. Small-island agroforestry in an era of climate change and sustainable development goals. In Sustainable Development Through Trees on Farms: Agroforestry in its Fifth Decade; van Noordwijk, M., Ed.; World Agroforestry (ICRAF): Bogor, Indonesia, 2019; pp. 233-248.

137. Chan, H.T.; Baba, S. Manual on Guidelines for Rehabilitation of Coastal Forests Damaged by Natural Hazards in the Asia-Pacific Region; International Society for Mangrove Ecosystems and International Tropical Timber Organization (ITTO): Yokahama, Japan, 2009; Available online: http://www.preventionweb.net/fies/13225_ ISMEManualoncoastalforestrehabilita.pdf (accessed on 20 July 2020).

138. Global Nature Fund. Mangrove Restoration Guide, Best Practices and Lessons Learned from a Community-Based Conservation Project; Global Nature Fund: Radolfzell, Germany, 2015; Available online: https://www. globalnature.org/bausteine.net/f/8281/GNF_Mangrove_Handbook_2015.pdf?fd=0 (accessed on 20 July 2020).

139. Sasmito, S.D.; Murdiyarso, D.; Friess, D.A.; Kurnianto, S. Can mangroves keep pace with contemporary sea level rise? A global data review. Wetl. Ecol. Manag. 2016, 24, 263-278. [CrossRef]

140. Wong, M.H. Ecological restoration of mine degraded soils, with emphasis on metal contaminated soils. Chemosphere 2003, 50, 775-780. [CrossRef]

141. Hairiah, K.; van Noordwijk, M.; Sari, R.R.; Saputra, D.D.; Widianto; Suprayogo, D.; Kurniawan, S.; Prayogo, C.; Gusli, S. Soil carbon stocks in Indonesian (agro)forest transitions: Compaction conceals lower carbon concentrations in standard accounting. Agric. Ecosyst. Environ. 2020, 294, 106879. [CrossRef] 
142. van Noordwijk, M.; Goverse, T.; Ballabio, C.; Banwart, S.; Bhattacharyya, T.; Goldhaber, M.; Nikolaidis, N.; Noellemeyer, E.; Zhao, Y.; Mline, E. Soil carbon transition curves: Reversal of land degradation through management of soil organic matter for multiple benefits. In Soil Carbon: Science, Management and Policy for Multiple Benefits; Banwart, S.A., Noellemeyer, E., Milne, E., Eds.; CAB International: Harpenden, UK, 2015; pp. 26-46.

143. Minasny, B.; Malone, B.; McBratney, A.B.; Angers, D.; Arrouays, D.; Chambers, A.; Chaplot, V.; Chen, Z.-S.; Cheng, K.; Das, B.S.; et al. Soil carbon 4 per mille. Geoderma 2017, 292, 59-86. [CrossRef]

144. Tomich, T.P.; van Noordwijk, M.; Budidarsono, S.; Gillison, A.N.; Kusumanto, Y.; Murdiyarso, D.; Stolle, F.; Fagi, A.M. Agricultural intensification, deforestation, and the environment: Assessing tradeoffs in Sumatra, Indonesia. In Tradeoffs or Synergies? Agricultural Intensification, Economic Development and the Environment; Lee, D.R., Barrett, C.B., Eds.; CAB-International: Wallingford, UK, 2001; pp. 221-244.

145. Tomich, T.P.; van Noordwijk, M. Trade-off matrix between private and public benefits of land-use systems (ASB Matrix). In Negotiation-Support Toolkit for Learning Landscapes; van Noordwijk, M., Lusiana, B., Leimona, B., Dewi, S., Wulandari, D., Eds.; World Agroforestry Centre (ICRAF): Bogor, Indonesia, 2013; pp. 118-119.

146. Dewi, S.; Ekadinata, A.; Galudra, G.; Agung, P.; Johana, F. LUWES: Land use planning for low emission development strategy. World Agrofor. Cent. Bogor. Indones 2011. 47p. Available online: http://www. worldagroforestry.org/output/land-use-planning-low-emission-development-strategy-luwes (accessed on 20 July 2020).

147. Neely, C.; Bourne, M.; Chesterman, S.; Kouplevatskaya-Buttoud, I.; Bojic, D.; Vallée, D. Implementing 2030 Agenda for Food and Agriculture: Accelerating Impact through Cross-Sectoral Coordination; World Agroforestry Centre (ICRAF) and Food and Agricultural Organization of The United Nations (FAO): Nairobi, Kenya; Rome, Italy, 2017; Available online: http://www.fao.org/3/a-i7749e.pdf (accessed on 20 July 2020).

148. Clark, W.C.; Tomich, T.P.; Van Noordwijk, M.; Guston, D.; Catacutan, D.C.; Dickson, N.M.; McNie, E. Boundary work for sustainable development: Natural resource management at the Consultative Group on International Agricultural Research (CGIAR). Proc. Natl. Acad. Sci. USA 2016, 113, 4615-4622. [CrossRef]

149. Robiglio, V.; Reyes, M. Restoration through formalization? Assessing the potential of Peru's Agroforestry Concessions scheme to contribute to restoration in agricultural frontiers in the Amazon region. World Dev. Perspect. 2016, 3, 42-46. [CrossRef]

150. Villamor, G.B.; van Noordwijk, M.; Leimona, B.; Duguma, L. Tradeoffs. In Co-Investment in Ecosystem Services: Global Lessons from Payment and Incentive Schemes; Namirembe, S., Leimona, B., van Noordwijk, M., Minang, P.A., Eds.; ICRAF: Nairobi, Kenya, 2017; Chapter 3; Available online: http://www.worldagroforestry. org/sites/default/files/chapters/Ch3\%20Trade-offs_ebookB-DONE2.pdf (accessed on 20 July 2020).

151. Suwarno, A.; van Noordwijk, M.; Weikard, H.P.; Suyamto, D. Indonesia's forest conversion moratorium assessed with an agent-based model of Land-Use Change and Ecosystem Services (LUCES). Mitig. Adapt. Strat. Glob. Chang. 2018, 23, 211-229. [CrossRef]

152. Amaruzaman, S.; Leimona, B.; van Noordwijk, M.; Lusiana, B. Discourses on the performance gap of agriculture in a green economy: A Q-methodology study in Indonesia. Int. J. Biodivers. Sci. Ecosyst. Serv. Manag. 2017, 13, 233-247. [CrossRef]

153. Langston, J.; McIntyre, R.; Falconer, K.; Sunderland, T.J.C.; van Noordwijk, M.; Boedihartono, A.K. Discourses mapped by Q-method show governance constraints motivate landscape approaches in Indonesia. PLoS ONE 2019, 14, e0211221. [CrossRef]

(C) 2020 by the authors. Licensee MDPI, Basel, Switzerland. This article is an open access article distributed under the terms and conditions of the Creative Commons Attribution (CC BY) license (http://creativecommons.org/licenses/by/4.0/). 